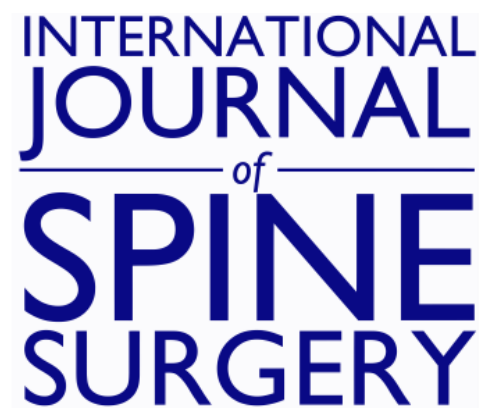

\title{
The "inside out" transforaminal technique to treat lumbar spinal pain in an awake and aware patient under local anesthesia: results and a review of the literature
}

Satishchandra Gore and Anthony Yeung

Int J Spine Surg 2014, 8 ()

doi: https://doi.org/10.14444/1028

http://ijssurgery.com/content/8/28

This information is current as of April 26, 2023.

Email Alerts Receive free email-alerts when new articles cite this article. Sign up at:

http://ijssurgery.com/alerts

The International Journal of Spine Surgery

2397 Waterbury Circle, Suite 1,

Aurora, IL 60504, Phone: +1-630-375-1432 


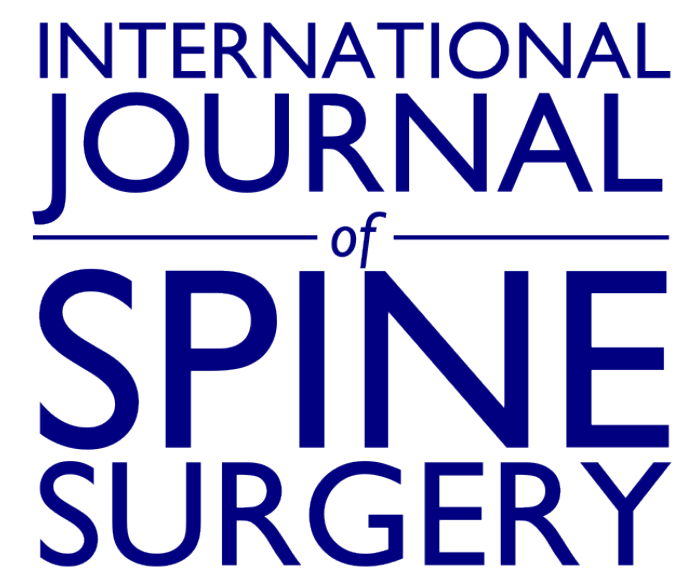

This article generously published free of charge by the International Society for the Advancement of Spine Surgery.

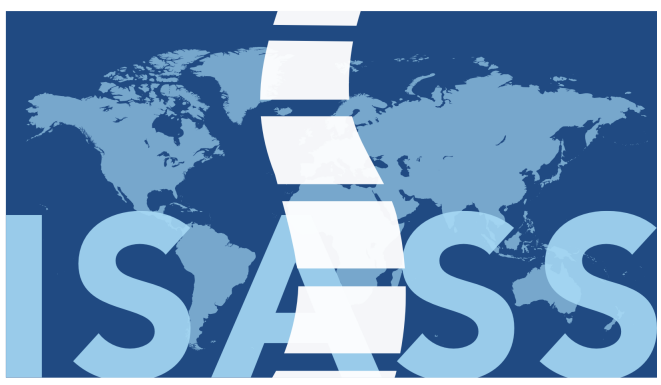

INTERNATIONAL SOCIETY for the ADVANCEMENT of SPINE SURGERY 


\section{The "inside out" transforaminal technique to treat lumbar spinal pain in an awake and aware patient under local anesthesia: results and a review of the literature}

Satishchandra Gore, $M D,{ }^{1}$ Anthony Yeung, $M D^{2}$

${ }^{1}$ Prime Surgical Centre, Pune, India ${ }^{2}$ Desert Institute for Spine Care, Phoenix, AZ, USA

\section{Abstract}

Surgical management of back and leg pain is evolving and changing due to a better understanding of the patho-anatomy well correlated with its pathophysiology. Pain is better understood with in vivo visualization and probing of the pain generators using an endoscopic access rather than just relying on symptoms diagram and image correlation. This has resulted in a shared decision making involving patient and surgeon, focused on a broader spectrum of surgical as well as non-surgical treatments, and not just masking the pain generator. It has moved away from decisions based on diagnostic images alone, that, while noting the image alterations, cannot explain the pain experienced by each individual as images do not always show variations in nerve supply and patho-anatomy.

The ability to isolate and visualize "pain" generators in the foramen and treating persistent pain by visualizing inflammation and compression of nerves, serves as the basis for transforaminal endoscopic (TFE) surgery. This has also resulted in better pre surgical planning with more specific and defined goals in mind. The "Inside out" philosophy of TFE surgery is safe and precise. It provides basic access to the disc and foramen to cover a large spectrum of painful pathologies. 


\section{Introduction to transforaminal endoscopy: the "inside out" technique}

Surgical management of back and leg pain is evolving and changing due to a better understanding of the patho-anatomy well correlated with its pathophysiology. Pain is better understood with in vivo visualization and probing of the pain generators using an endoscopic access rather than just relying on symptoms diagram and image correlation. This has resulted in a shared decision making involving patient and surgeon, focused on a broader spectrum of surgical as well as non-surgical treatments, and not just masking the pain generator. Clinical diagnosis has moved away from decisions based on diagnostic images alone, that, while noting the image alterations, cannot explain the pain experienced by each individual as images do not always show variations in nerve supply and patho-anatomy.

The ability to isolate and visualize the "pain" generators in the foramen and treating persistent pain by visualizing inflammation and compression of nerves, serves as the basis for transforaminal endoscopic (TFE) surgery. ${ }^{1,2}$ This has also resulted in better pre surgical planning with more specific and defined goals in mind. The "inside out" philosophy of TFE surgery is safe and precise. It provides a least invasivebasic access to the disc and foramen to cover a large spectrum of painful pathologies.

\section{Method}

In 2001 Yeung and Gore published ${ }^{1}$ the then evolving methodology with emphasis on skin markings, trajectory to the foramen, and visualization of the basic pathology of annular tears which caused the pain of discogenic origin. ${ }^{2}$ In 2002, Yeung and Tsou ${ }^{3}$ described the YESS TFE technique with specialized instruments able to treat all forms of disc herniation by the transforaminal approach. The technique is always performed under local anesthesia. The use of $1 \%$ or $.50 \%$ lidocaine permits generous use for pain control but allows the patient to feel pain when the inflamed nerve root is manipulated. The patient, under a local anesthetic, usually remains comfortable during the entire procedure, with the exception of periods such as during Evocative Chromo-Discography, annular fenestration, or when instruments are manipulated next to the exiting and traversing nerves. Evocative Chromo-discography is performed in every surgical case to get anatomic feedback by correlating the discogram pattern fluoroscopically and by "evoking the patient's response of pain as Negative, concordant, similar, or discordant. This facilitates interpretation of the disc degenerative pattern and labels the degenerative disc for guided extraction or no extraction endoscopically. Degenerative disc is stained by a $10 \%$ mix of indigocarmine dye with a non-ionic radio opaque dye. As the degenerative acidic blue stained nucleus is removed, the inner annulus is visualized for loose degenerative disc material caught in the torn annulus. Chronic non healing annular tears and nuclear material caught in tears is a common cause of chronic low back pain. The annulus is inspected for tears and modulated as needed. Intradiscal thermal modulation then treats the tear from the inside- out. The endoscope is then withdrawn from center of disc to foramen to inspect the foramen, the exiting nerve, and the epidural space as needed. Extruded disc fragments are accessed after foraminoplasty with a foraminoplasty scope and its accompanying instruments. Probing ventral and dorsal to the traversing 
nerve and the axilla of the exiting nerve confirms adequate removal of all mechanical lesions. Tissue in the axilla between the exiting and traversing nerve is cleared if a foraminal osteophyte or disc fragment or residual disc fragment is suspected. $80 \mathrm{mg}$ of depomedrol and 2cc .5\% Marcaine is deposited in the foramen at the end of the procedure. In cases where we suspect inadequate decompression of the lateral canal or hidden zone of Macnab, we go in the subarticular zone and decompress the ventral facet and the roof of the upper foramen.

A standardized technique of TFE with crystallized learning objective of precise needle placement to the pain generator, the YESS system is detailed by Yeung. ${ }^{4,5,6}$ The procedure is carried out in an operating room, using local anesthesia and conscious sedation attended by an anesthesiologist. The patient is prone, positioned on a radiolucent frame, with the position of the imaging equipment, instrument table, and operating room personnel in relation to the surgeon shown in Figure 1.

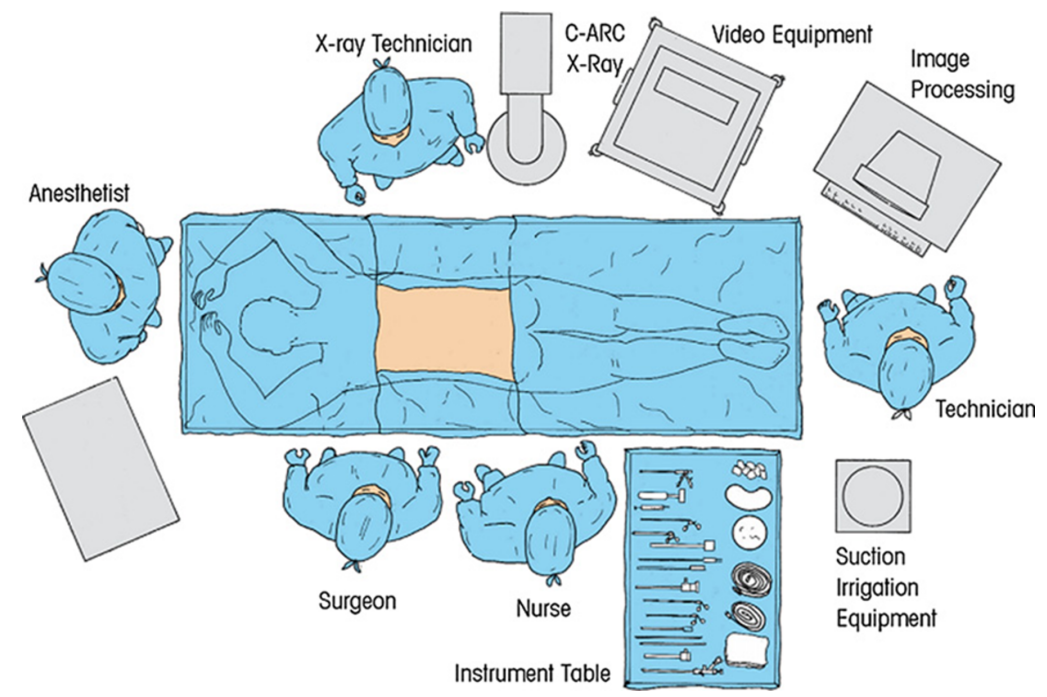

Fig. 1.

The conscious patient is instructed to report any unusual painful sensations to the operating surgeon while the procedure is in progress. Although some surgeons utilize the lateral position, the prone position is preferred, as the prone position allows a biportal (bilateral) approach if necessary. This helps with real time visualization of large and flexible working instruments in the disc while the operating endoscope in the contralateral port (foramen) simultaneously directs smaller instruments through the operating channel during discectomy. It is more common to use uniportal approach as it is sufficient to address most common issues. ${ }^{7,8}$

Biplane intraoperative fluoroscopic images are employed for percutaneous guidance. The approach trajectory starts from an optimally located skin window entering the disc through the foraminal annular window. This starting point is calculated by drawing the trajectory on the skin by a protocol described as part of the YESS technique for needle placement. We are between longissimus and psoas. 
A.

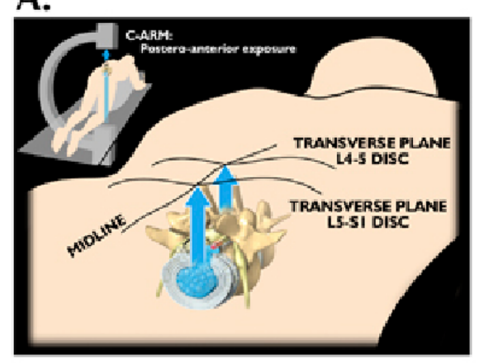

C.

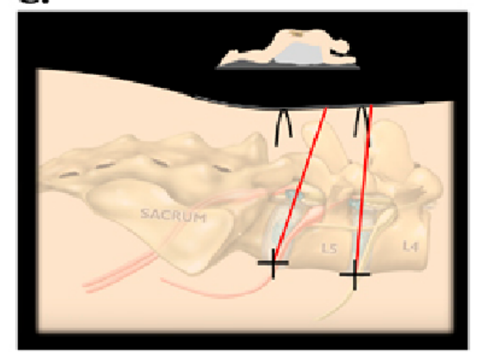

E.

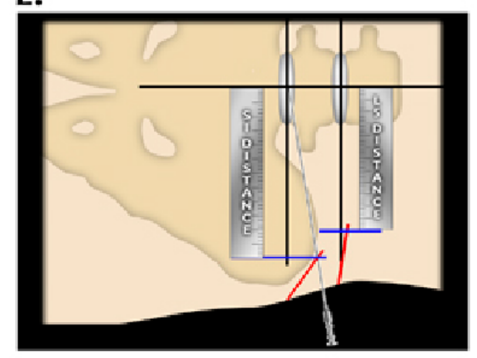

B.

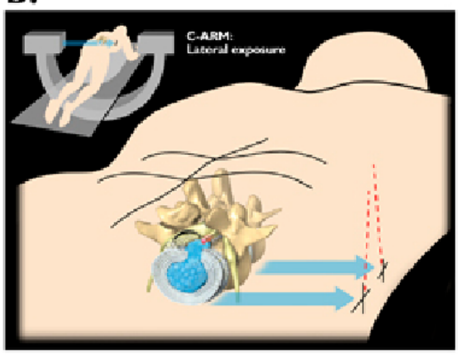

D.

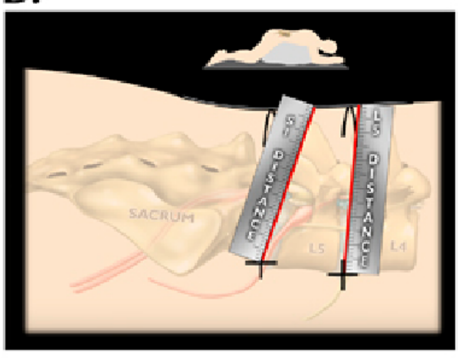

F.

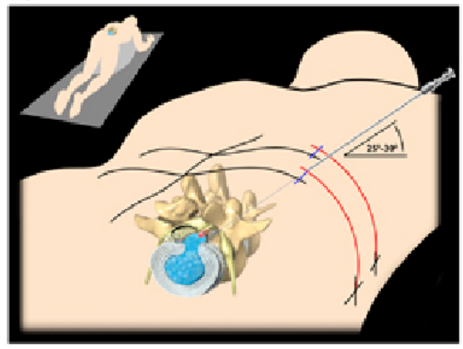

Fig. 2. Changed trajectory to 20-30 degrees.

First, a needle is inserted into the disc without causing leg pain, then the exiting nerve is retracted from harm's way with a dilator. By using a beveled or other similarly configured cannula as a tubular retractor and a surgical access tunnel, the disc is entered. In an insideout- technique, a cavity in the disc must be created for viewing and manipulating the endoscopic tools intradiscally. In disc herniations, space is naturally already created by displacement of the fragment from inside the disc to the epidural space. Some endoscopic surgeons target the extruded herniated fragment directly by placing a guide wire to the disc fragment, then using dilating cannulas and cutting instruments into the epidural space to address the herniation using blind fluoroscopically guided cutting of the facet (outside in technique). The outside in technique is fraught with danger to neuro vascular and ligamentous structures in foramen which may be harmed due to the blind nature of the access technique. 

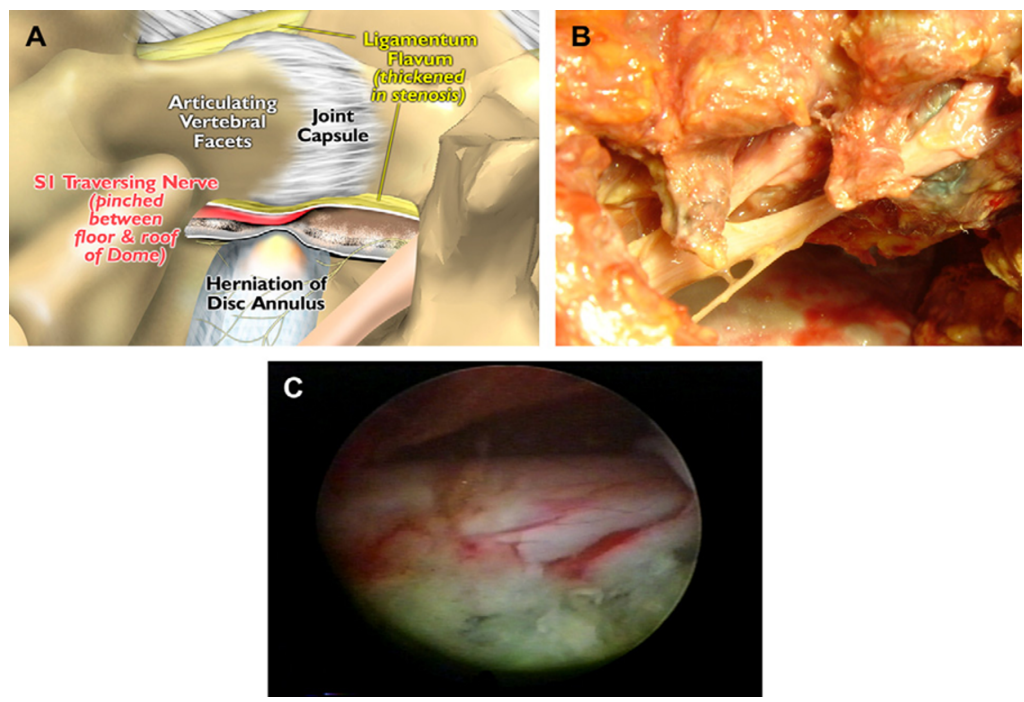

Fig. 3. shows structures in foramen which we come across when targeting the disc. Note facet forms roof of the lower foramen

The initial change in cases of disc degeneration is an annular tear. The tear may leak and cause inflammation around nerve root or DRG. The weakened annulus may give rise to a subsequent herniation through this tear, so we must target the fragment, annular tear, and the leak from the tear. Physiologically, the inflammation gives rise to mechanosensitization of the nerve roots and DRG, which requires removal of the embedded disc fragments in the annulus to allow that torn annulus to heal. Access is by a needle directed in a shallow trajectory to enable instruments to remove the embedded disc fragments in the tear. For visualized thermal modulation, access is then dilated by using an obturator which makes way for a working sheath that accommodates an endoscope. Thus, introduction of an endoscope without any tissue cutting is desired. The landing of instruments is in the foramen below the facet in the safe triangle as described by Kambin. Figure 4 highlights cadaver dissection showing same area accessed by open or endoscopic method. Figure 5 is Kambin's triangle. Further alterations to a more horizontal trajectory, if needed, is accomplished by foraminoplasty by facet under cutting to facilitate removal of disc fragments from the annulus. The landing point is between the medial and lateral pedicular border. In cases of hypertrophied tissue in the foramen, our efforts are directed to the roof of the foramen. 


\section{Comparative Surgical Anatomy}

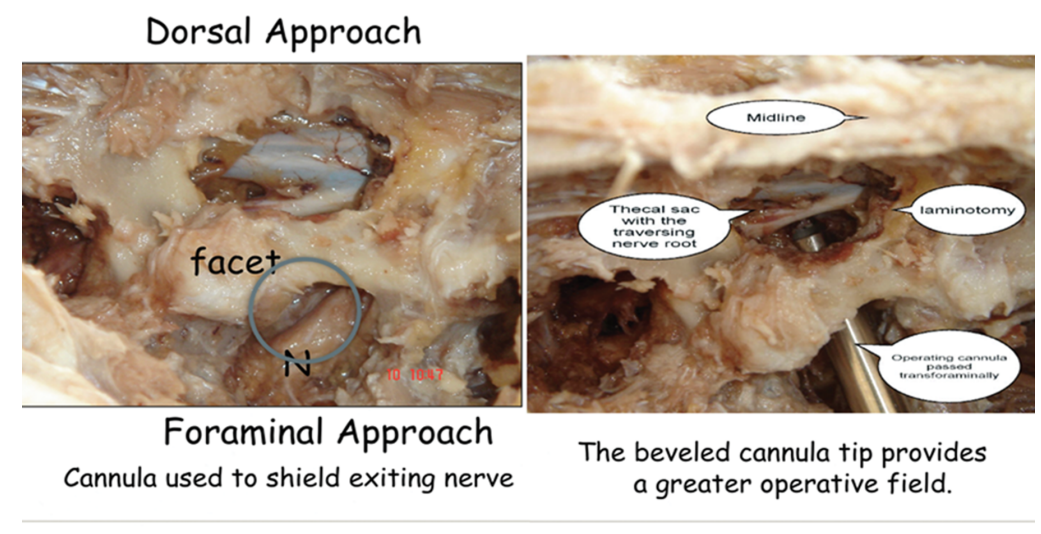

Fig. 4.

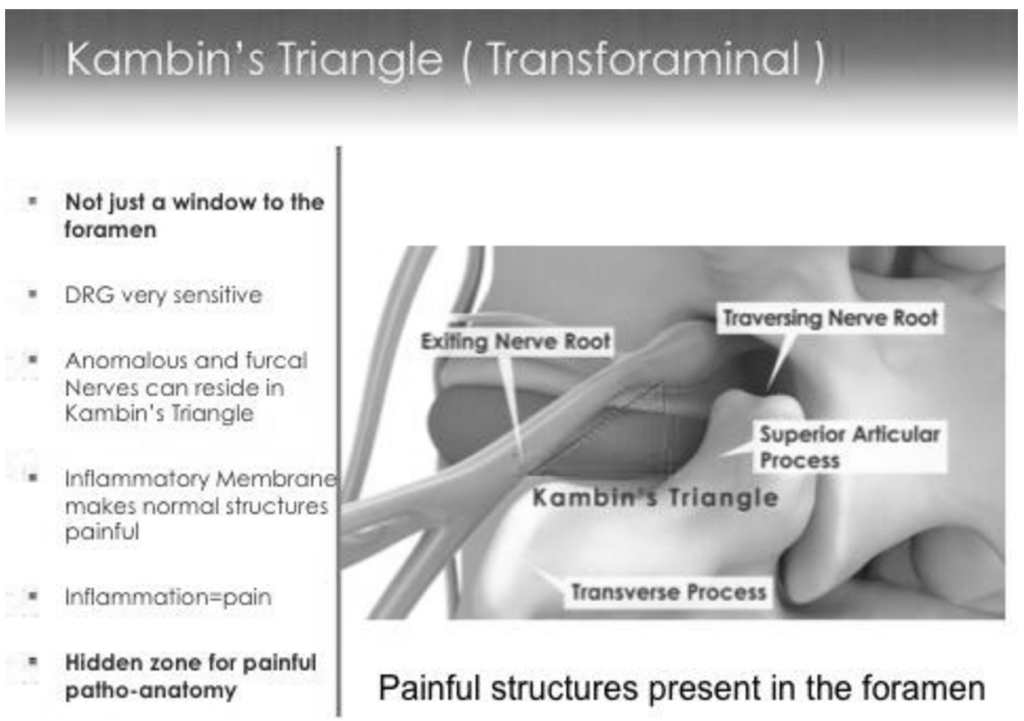

Fig. 5.

Selective endoscopic discectomy (SED) surgery does not need general anesthesia, blood transfusion, or skin sutures, and thus is very simplified. It is done under local anesthesia with conscious sedation. Only small adhesive skin strips are needed to close the skin. A single suture may be used to close the $.8 \mathrm{~cm}$ incision, because of its size, sutures are not necessary. Any bleeding from the incision site will stop by the time the patient is becomes supine and then brought to the recovery room.

The newest added technique is to target the superior facet and walk the needle down the ventral bony facet, hugging the facet to avoid the exiting nerve and using the facet as a lever arm to perform foraminoplasty and / or the use the facet as a fulcrum to change trajectories of endoscopic cannulas and instruments for removal of large fragments as shown in Figure 6. 


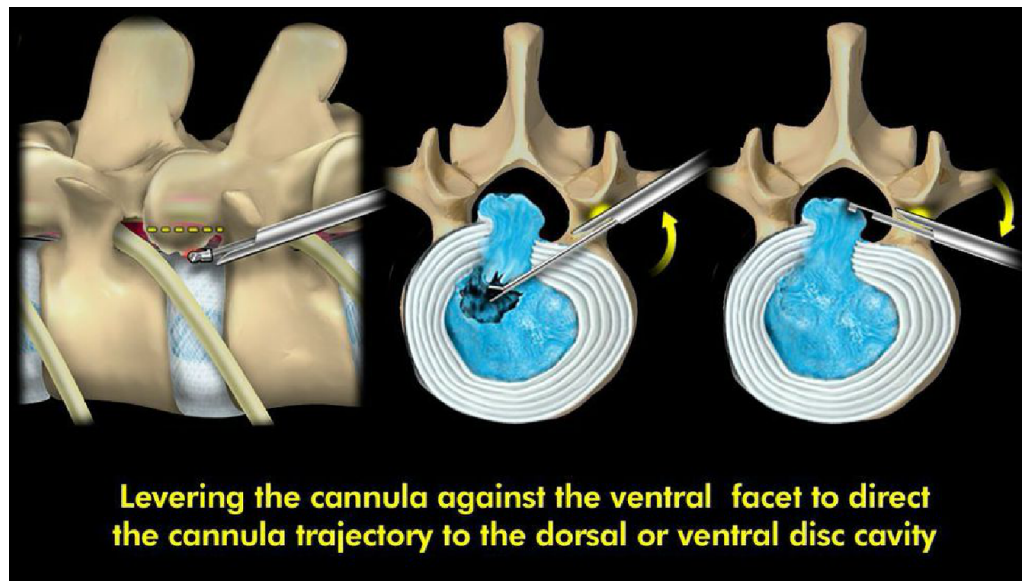

Fig. 6.

Currently available equipment include high resolution rod lens operating endoscopes, beveled cannulas, trephine, endoscopic kerrison, bipolar RF electrode, straight and side firing Holmium-YAG laser, and a high speed diamond and articulated based burr. Each tool has a unique role in performing special surgical tasks with various sized access cannulas and scopes. Recent addition of a hook and flexible curette which can extend reach to epidural area and migrated fragments makes removal of those fragments easier and possible at times without removal of bone. The addition of a curette helps in cutting the tip of the superior articular process (SAP) to expose the hidden zone and deroof and decompress the DRG and axilla of the root in the lateral canal. A curette is seen on the SAP of the facet in Figure 7. 


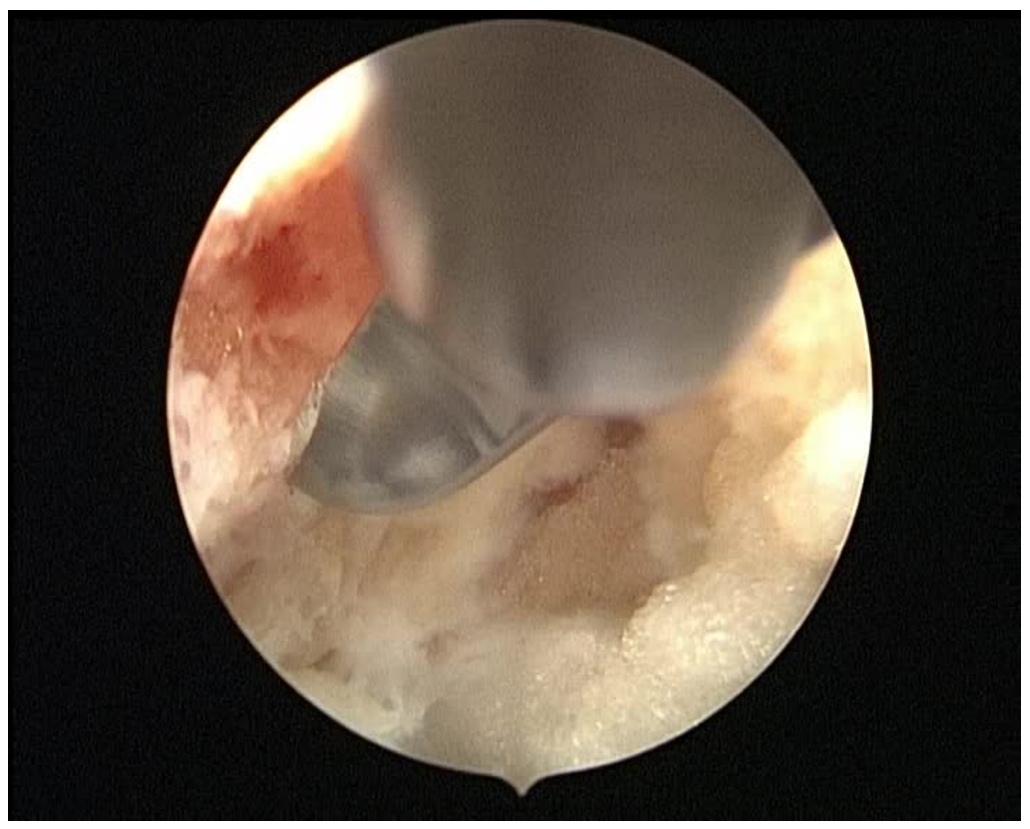

Fig. 7.

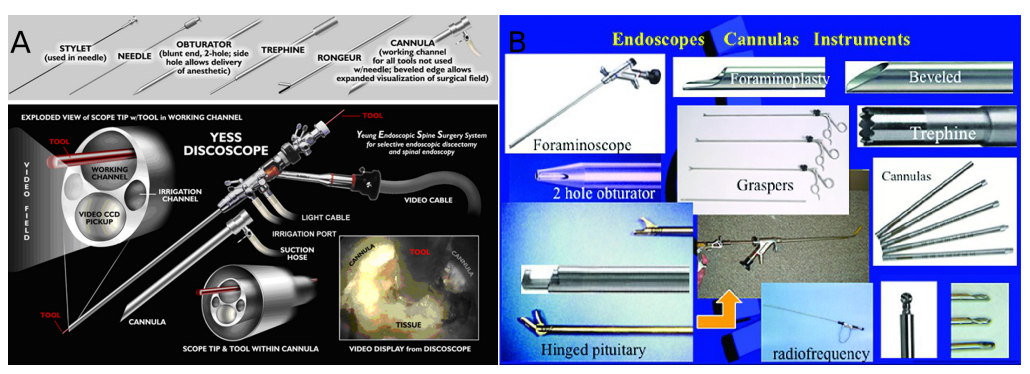

Fig. 8.

A. The Richard Wolf YESS endoscope facilitates endoscopic documentation of pathoanatomy. The uniqueness of the YESS scope is the $2.8 \mathrm{~mm}$ working channel with integrated distal irrigation ports that keep the lens clear of blood that may otherwise obscure Intradiscal and epidural visualization.

B. In addition to custom instruments used by the senior author (ATY), Wolf has a full complement scopes and instrumentation designed for disc inspection, disc excision, foraminal decompression, and ablation. An additional complement of scopes with working channels and instruments offer operating ports of 2.2, $2.8,3.1$, and $4.2 \mathrm{~mm}$ are used for discectomy, rhizotomy, foraminoplasty and for the trans foraminal and translaminar approach to the lumbar spine. 


\section{Results}

Yeung and Tsou ${ }^{3}$ reported TFE in his first 307 patients with disc herniations who were candidates for transcanal microdiscectomy. The study included intracanal and extracanal herniations. Recurrent herniations and patients with previous surgery at the same level were not excluded. Results were reported after a 1-year follow up. SEDincluded extruded, migrated, sequestered HNP at all levels felt possible by the operating surgeon. Average VAS was decreased from 6.6 to 2.5 and ODI decreased from $46 \%$ to $32 \%$. Thirty-seven patients $(15 \%)$ developed temporary dysesthesia in the 2-week postoperative period. Even with dysesthesia, improvement in VAS and ODI was comparable to MLD. Ninety-one percent of the patients were satisfied with their results and would opt to undergo the procedure again if they had the same diagnosis and symptoms. The overall complication rate was reported to be $4 \%$.

Tsou and Yeung ${ }^{71}$ separated out a subgroup of 219 patients with non-contained herniations and reported the results at 1 year. Patient satisfaction was $91 \%$. TFE could provide equivalent results to reported results of open microdiscectomy, even with noncontained, extruded herniations.

Yeung reported in $2013^{80} 50$ Cases of micro- lumbar discectomy (MLD) compared with SED: MLD L4-5=15,L5-S1=35. Average VAS Decreased from 6.5 to 1.7. Average ODI Decreased from $44 \%$ to $30 \%$. Complications $=1$ seroma, 1 durotomy. Patients receiving MLD were usually for extruded, migrated, or sequestered HNP believed better suited for MLD and more difficult for SED. Patient receiving MLD was due to surgeon advice and preference. Patient satisfaction was $92 \%$. Patients in Yeung's spine practice, however, were mostly referred for and mostly sought and chose SED when given a choice by the surgeon.

The SED group numbered 137, with 209 total levels: L1-2=1, L2-3=3 L3-4=31, L4-5=94, L5-S1 $=80$. Average VAS was 6.6 and ODI was $46 \%$. Improvement in the SED group was 4.1 and $32 \%$. Endoscopic decompression included foraminoplasty for lateral stenosis. In the endoscopic group, 20 patients (14.7\%) developed dysesthesia in the 2 week postoperative period. In spite of the inclusion of more complex degenerative spine problems in patients who were also candidates for decompression and fusion, improvement in VAS and ODI was comparable to MLD at 4.1 and $32 \%$ respectively. Patient satisfaction was over $90 \%$, since many chose SED over MLD even in the face of disc extrusion at L5-S1.

Yeung has continued to report on the evolution of his work at numerous national and international peer reviewed meeting, but has not published the result of his stratified techniques for specific conditions in an aging spine such as degenerative spondylolisthesis, lumbar spondylosis, and foraminal stenosis. He has maintained his goal, however, of a $90 \%$ patient satisfaction rate as a personal standard for his patients as he takes them on with a first line surgical treatment where his patients want to avoid traditional surgery. They are satisfied with partial improvement by VAS, Oswestry disability index, and SF-12 measurements. He has successfully relieved pateints' pain from mild deformity and instability by offering endoscopic decompression, ablation, and irrigation in patients who want to try the least invasive method first, even in the face of 
conditions that are ideal for traditional decompression, fusion, and stabilization. He has experienced, first hand, his own condition of a three level stenosis with a tri modal HNP in the face of degenerative scoliosis and grade one spondylolisthesis. He had his endoscopic decompression as a staged procedure, performed only under local anesthetic and no sedation before undergoing a 3-level decompression and coflex implant at L4-5. Each surgical procedure provided the relief, in stages required at the time.

\section{Variations in technique}

We have 2 variations in basic access. 1. An inside out 25-35 degree angle or far lateral 10-20 degree approach that uses the ventral aspect of the superior articular process facet as a fulcrum, to angle the trajectory, or 2. Transforaminal access from an "outside in" with fluoroscopically guided facet under cutting but with the aid of an endoscope and special access cannula.

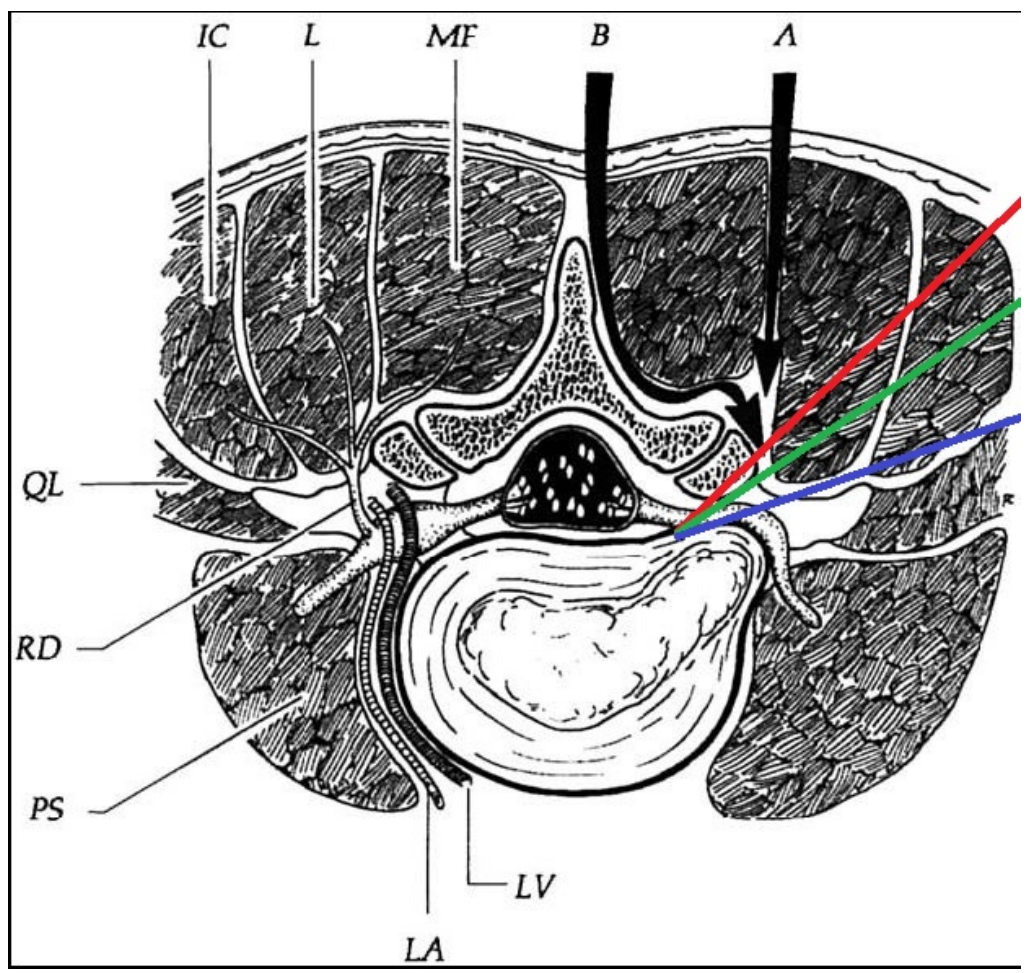

Fig. 9.

The red line represents the outside in access which cuts the undersurface of the facet to get to the herniation, especially in extruded fragments. The green line is the standard transforaminal access proposed by Yeung (we may graze the facet surface). The blue arrow will be representing access by Ruetten who named it an extreme lateral access. It is more flat and may go under the intertransverse ligament plane. All will land at same place in safe triangle, targeting the fragment directly versus indirectly but since the trajectory is different and scope lens angle may differ from $15-25^{\circ}$, structures seen may be little different. In the red line access we have to cut the facet to see more of the epidural structures. In the green line we land inside disc, and after finishing our job inside and visualizing annular tear, we can access epidural structures by cutting the annulus, by 
changing trajectory by levering against the ventral facet, or with foraminoplasty. The blue line trajectory represents the extreme lateral access which shows more epidural structures even at start.

A new paradigm shift to in vivo visualization of patho-anatomy that augments radiographic images with endoscopic images ${ }^{7,8}$ is now feasible. The learning and insight which a surgeon gets by operating on patients under local anesthesia and visualizing pain generators allows the surgeon to make better decisions and actions.

In experienced hands, some surgeons have safely utilized general anesthesia when circumstances make it safer for the patient who cannot hold still in prone position. ${ }^{9}$ Some patients, including the senior author (ATY) has experienced TFE surgery first hand without sedation. Pain experienced then by the patient is very helpful to the surgeon when probing or operating in the foramen, as he can then look to document or free periradicular adhesions before removing the herniation. The visualization of a herniated fragment, conjoined nerves, furcal nerve branches, and anomalous anatomy such as sympathetic nerves sheds light on why current imaging studies cannot fully explain the reason(s) that some patients with identical imaging studies have debilitating pain and others do not.

Most spine surgeons unfamiliar with TFE may not attempt to remove extruded, sequestered disc herniations because they are much more familiar and adept with the traditional transcanal approach. They reserve the approach for contained and foraminal or extraforaminal disc herniations because in their hands, traditional techniques provide more predictable surgical results. This is not a barrier for experienced endoscopic surgeon, who individualizes each indication by selecting the best approach for the patient. The "outside in" access does target the intracanal fragment directly after cutting the facet blindly and is practiced by experienced surgeons. The far lateral access to the epidural space targets the disc fragment directly. We think it is safer to visualize and enter the foramen and disc first under endoscopic visualization. Both these variations have evolved from the basic inside out technique.

General Indications for TFE are

1. Annular tears with discogenic lumbar pain as determined by evocative discography, both positive and false negative

2. All disc herniations and protrusions accessible through the foramen whether contained, extruded, or sequestered.

3. Extraforaminal Herniations

4. FBSS from foraminal fibrosis, recurrent HNP, and subarticular lateral recess stenosis

5. Mild and soft tissue central spinal stenosis

6. Foraminal and extraforaminal stenosis

7. Foraminal osteophytosis

8. Discitis

9. Juxtafacet and pedunculated cysts

All disc levels from D10 to S1 are assessable. Regardless of the endoscopic techniques reported by various surgeon advocates in the literature, the absolute ideal indications are foraminal and extraforaminal disc herniations and discitis. These types of herniations and 
conditions have greater approach related surgical morbidity with the traditional translaminar and even paramedian posterior approach, especially at L5-S1. The technique described here is a standardized YESS technique. 


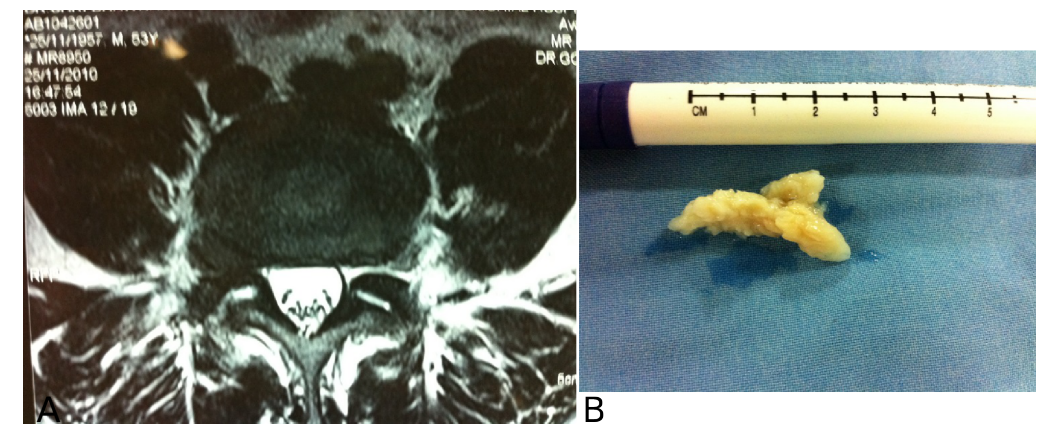

Fig. 10. Extraforaminal herniation.

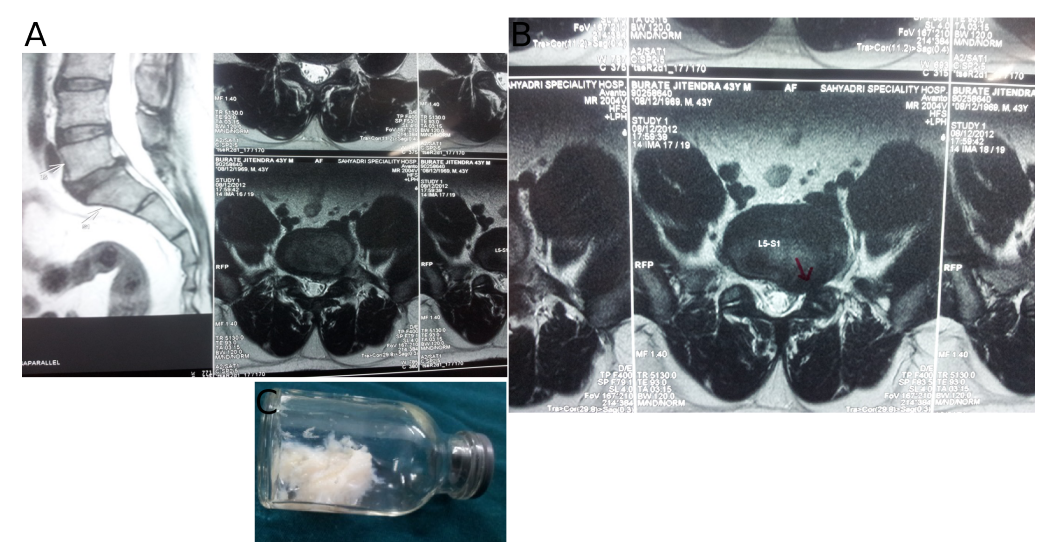

Fig. 11. Paracentral herniation.

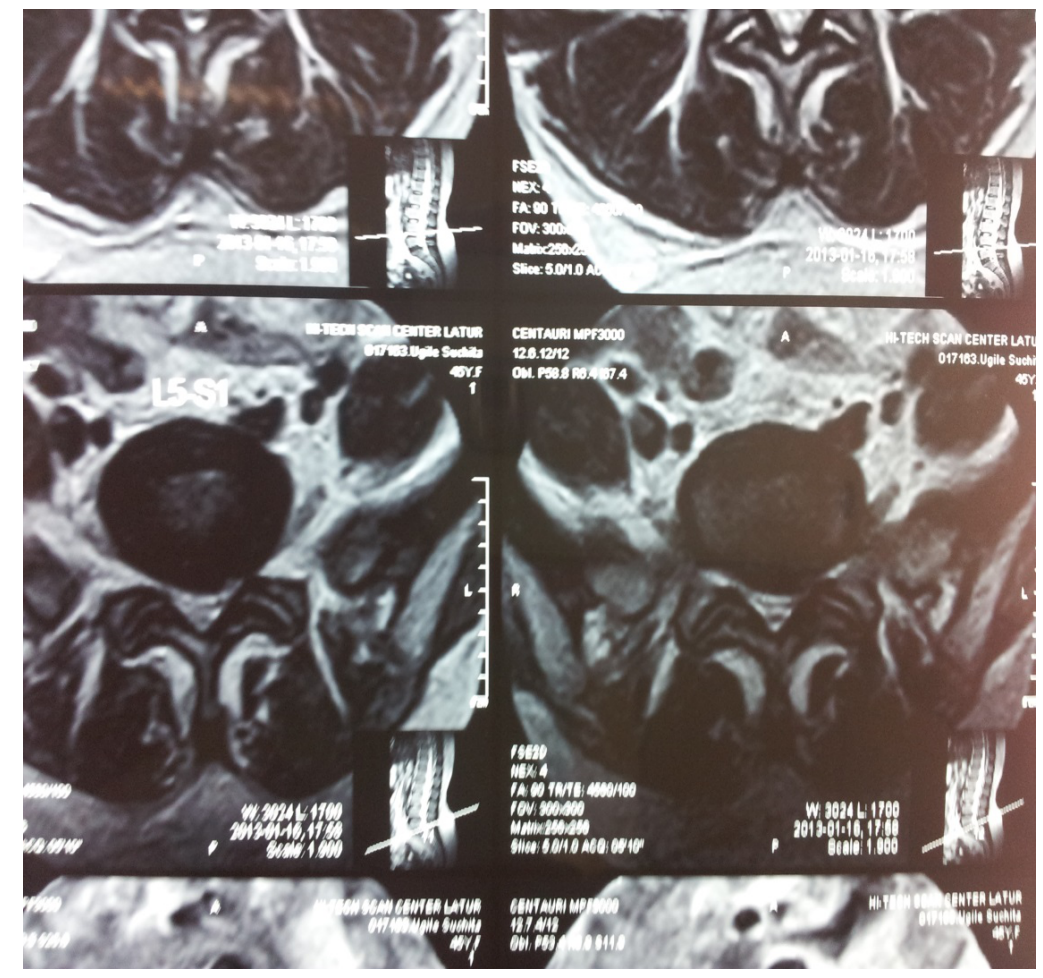

Fig. 12. Central herniation. 


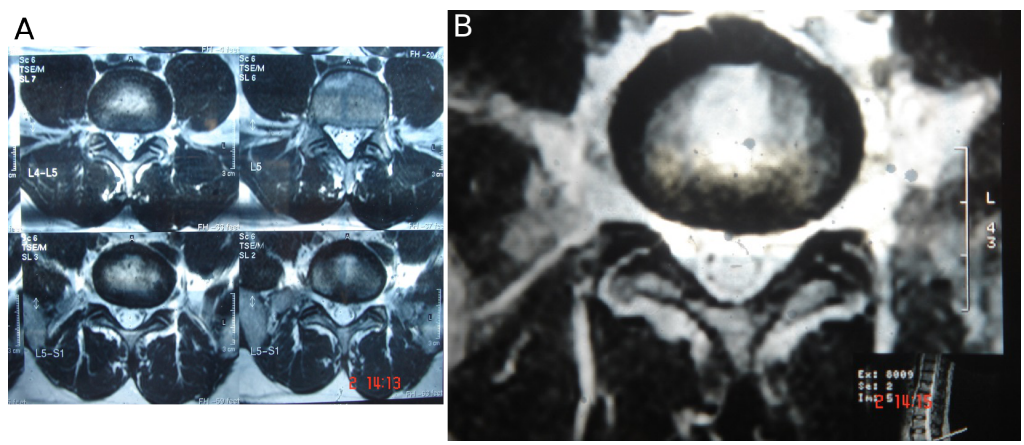

Fig. 13. Paracentral and foraminal left annular tear, which was treated successfully.

\section{Contraindications}

Endoscopic removal of disc herniation is only limited by the accessibility of endoscopic instruments to the herniation site. The location of the disc herniation, the extent of the extrusion and sequestration, and the experience level of the surgeon are vital considerations for patient selection. Some patients with high iliac crests, horizontal L5-S1 disc spaces, or degenerative scoliosis make surgical access through the foramen difficult. Contraindications thus are relative, and depend on the anatomic factors involved.

\section{Postoperative Regimen}

Prior to removal of the access cannula, routine use of depomedrol $80 \mathrm{mg}$ delivered with $.5 \%$ marcaine $(1-2 \mathrm{cc})$ will provide immediate postoperative analgesia; although there may be increased risk of infection, there have been no incidence of infection attributed to the use of steroids. In the absence of damaged tissue, discitis is very low. Post-op antibiotics may be considered for 24 hours post op when patient morbidity dictates its use. A postoperative lumbar corset will make the patient feel more comfortable. The patient should be instructed to avoid bending, lifting, and twisting for 4-6 weeks to allow the annulus to heal and to reduce the incidence of recurrent disc herniation from the foraminal access portal and from an annular defect of the disc herniation as well. Physical therapy is helpful, but not required, but can be considered on an individual basis. Patients are instructed to use their pain as a guide after the 6 week period. Some patients return to work and limited activity as soon as one day after surgery.

\section{Complications and Avoiding Pitfalls}

As with arthroscopic knee surgery, the risks of serious complications or injury are low-approximately $1 \%$ or less in the authors' experience. As with any surgery, there are the usual risks of infection, nerve injury, dural tears, bleeding, and scar-tissue formation. Transient dysesthesia, the most common postoperative complaint, occurs in approximately $5 \%-15 \%$ of cases, and is almost always transient. Its cause remains incompletely understood and may be related to nerve recovery, operating adjacent to the dorsal root ganglion of the exiting nerve, furcal nerves or a small hematoma adjacent to the ganglion of the exiting nerve, as it can occur days or even weeks after surgery. There are also anomalous nerve fibers in the annular tissue which may be furcal nerves or nerves growing into an inflammatory membrane in the area of the foramen that is not the traversing or exiting nerve. It could show up in the surgical specimen without permanent 
effect on the patient, but may cause temporary dysesthesia. Using blunt techniques to dilate the annular fibers has limited surgical morbidity but dysesthesia cannot be avoided completely. It can occur even when there were no adverse intraoperative events and in cases where the continuous electromyography (EMG) and somato-sensory evoked potentials (SEP) did not show any nerve irritation. The symptoms are sometimes so minimal that most endoscopic surgeons do not report it as a "complication."

The more severe dysesthetic symptoms are similar to a variant of complex regional pain syndrome, but usually less severe, and without the skin changes. postoperative dysesthesia is treated with transforaminal epidurals, sympathetic blocks, and the off-label use of Pregabalin or Gabapentin (Pfizer, Inc., New York, New York, USA) titrated to as much as $1800-3200 \mathrm{mg} /$ day. Gabapentin is FDA-approved for post-herpetic neuralgia, but effective in the treatment of neuropathic pain.

A thorough study of pre operative imaging and attention to details of the anatomy and its alterations can avoid the pitfalls in TFE.

\section{Discussion on the modern history of TFE}

The earlier history of the evolution of the technique has been covered in detail by Kambin et al. ${ }^{10}$

The technique described here was developed and 510K FDA approved in 1997 by Richard Wolf Surgical Instrument Company and Anthony Yeung, using his specialized multi-channel fluid integrated working channel YESS endoscope. ${ }^{9}$ Yeung deviated from Kambin's emphasis on staying out of the epidural space to confirm, with direct visualization, that extruded and sequestered disc herniations could be removed, but he maintained Kambin's commitment to the patho-anatomy inside the disc. Deviation of Kambin's original techniques was done if the pathoanatomy dictated the need to do so, by inspecting the traversing and exiting nerves under direct vision through his a working channel rigid endoscope. As Yeung's technique of "inside out" surgery developed it was simplified to the principles of selective endoscopic decompression (SED), ablation, and irrigation performed to address the pain generator whether in the disc or extradiscal and in the foramen. As the technique evolved we added decompression of the lateral canal by undercutting facet and SAP to gain access to the epidural space and also visualizing the "hidden zone" between the traversing and exiting nerve, a major location of failed back surgery syndrome (FBSS).

It has also given an edge over the traditional approach to failed back surgery, as now we are able to visualize the hidden zone (subarticular area; Figure 14). 


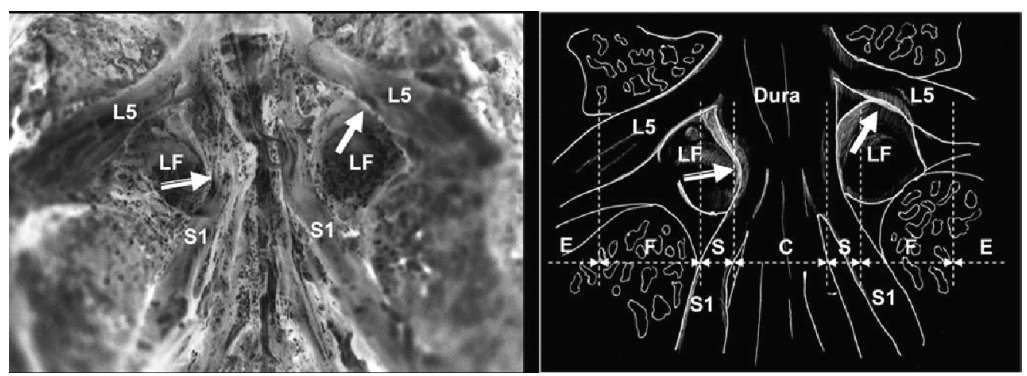

Fig. 14.

L5-S1 level showing nerve root compression by the ligamentum flavum (LF) in the subarticular zone (black arrow with white line inside a blue demarcated area) and foraminal zone (solid black arrow). The dotted lines in schematic diagram show the zone classification (Dura dura mater, L5 L5 nerve root, S1 S1 nerve root, E extraforaminal zone, $\mathrm{F}$ foraminal zone, $\mathrm{S}$ subarticular zone, $\mathrm{C}$ central canal) LF is ligamentum flavum in the axilla as seen from dorsal to ventral aspect in the foramen. This image highlights roof of the foramen over the kambin's triangle.

The literature also reflects the changing philosophy and capabilities in spine endoscopy and how we evolved. While the standardized methodology including access to the epidural space and technique was first published by Yeung and Gore in 2001, ${ }^{1,2}$ It is important and significant to note that a simultaneous change in understanding of the pain generators, pain mechanism and pain carriers led to an evolution of philosophy from a general decompression to a refined "selective" decompression, ablation, and irrigation technique at the site of inflammation and compression. Yeung and Gore have published in 2011 about in vivo visualization of pain generators in painful degenerative lumbar spine. ${ }^{7}$ For the sake of brevity we have described basic transforaminal access and then technique variations addressing varied pathologies in the painful functional spinal unit above.

The technique and equipment has undergone a slow, progressive evolution over the past thirty years with integration of added modalities in last 15 years. The major change has been adding larger working channels and new instruments to increase the reach and effectiveness at the target through the scope. Techniques by various spine surgeons may differ, but Yeung has tried to make it sufficiently standard that it is referred to as the YESS (Yeung Endoscopic Spine Surgery) technique using the YESS system. Since that time, the technique and its indications have continued to improve and evolve, expanding to include a wider spectrum of degenerative painful conditions of the lumbar spine. As a result of combining adjunctive minimally invasive technologies, and improvement in instrumentation, endoscopic capabilities in experienced hands now overlap the clinical efficacies of conventional transcanal open discectomies - but with less surgical morbidity well supported in literature.

While arthroscopic lumbar discectomy is a term first proposed by Parviz Kambin, through a working "triangular zone", the evolution and expansion of Kambin's technique since 1991 has made the term selective endoscopic discectomy more appropriate in describing Yeung's transforaminal "inside out" approach to the disc and foramen walls. This basic philosophy and methodology was published in 2001 by Yeung and Gore. 
There have been many variations in the techniques of transforaminal spine endoscopy, which have been based on instrument designs and treatment philosophy. Due to a relative absence of access related complications and alteration of normal anatomy, however, all surgeons adopting TFE access recognize it as the best surgical option, since it is more anatomical as well as physiological. TFE surgery is also greatly dependent on the "surgeon factor". All surgeons are trained to perform laminectomy/ discectomy, but few have the training and experience in endoscopic treatment of the degenerating functional spinal unit reaching all of its pathological variations. Each operating surgeon then places his own self directed method and an independent emphasis on his version of TFE surgery as it evolves.

Contributions from Gore have produced foraminoplasty and articulated instruments, hook and currette through an "inside-out approach" that go down a $3.625 \mathrm{~mm}$ working channel foraminal endoscope expands reach and indications even more for the individual surgeon, shortening his learning curve. 


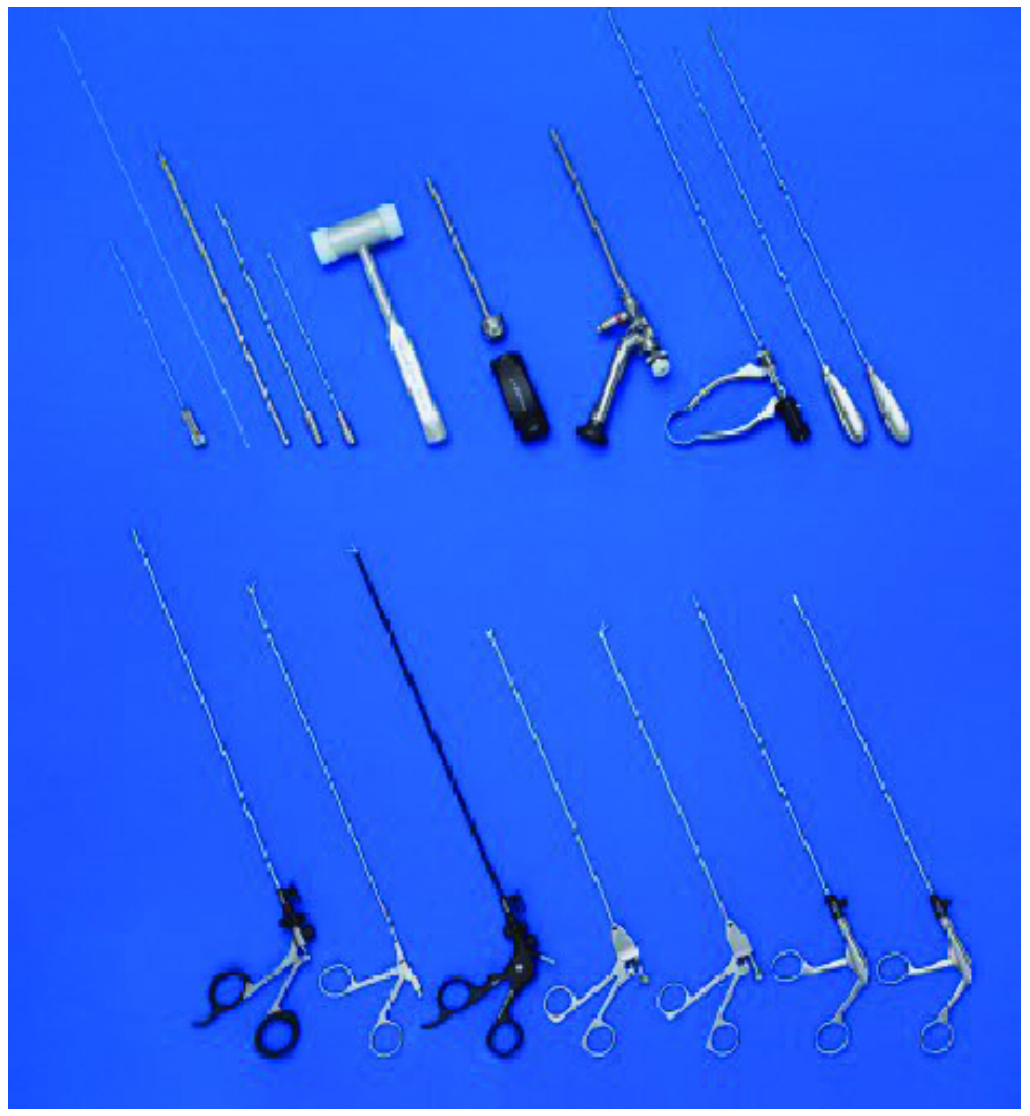

Fig. 15. Karl Storz Gore System of instruments for lumbar spine endoscopy and surgery. This set includes bipolar cautery probe, kerrison style roungeurs, angled articulated instruments, and trephines. In addition it has a drill, burr, and shaver set. The set has a $3.625 \mathrm{~mm}$ working channel, and instruments are specially configured for shorter Asian morphometry. It has a hook, which helps with probing, nerve mobilization and manipulation of annular tears. The basic set has 9 instruments needed for simplicity, but adequate for routine surgery.

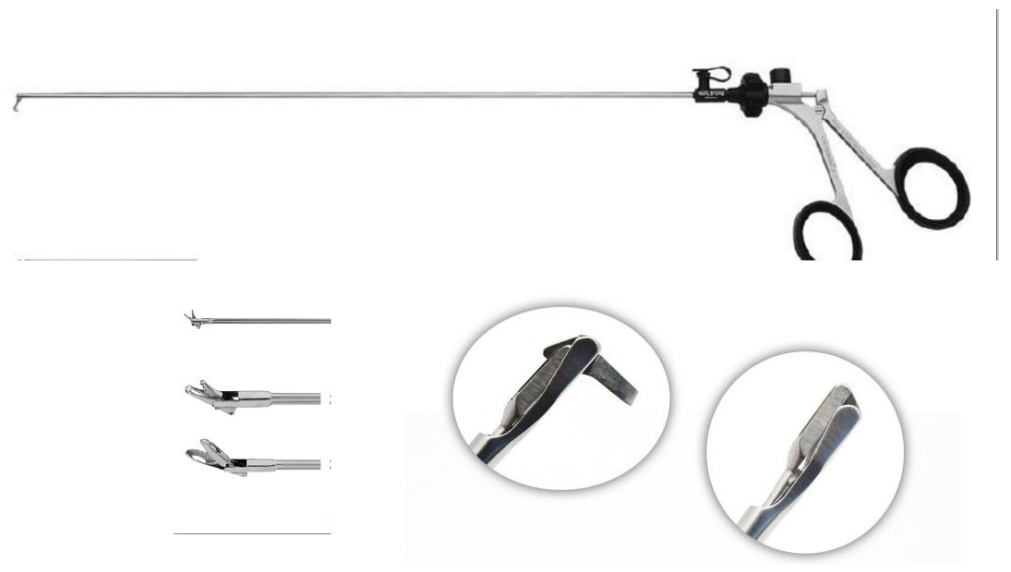

Fig. 16. Endoscopic instruments shown Illustrations show a 1 hook, 2 articulated graspers for targeting migrated fragments and 3 a back biter amongst others.

\section{History of traditional TFE}


True minimally invasive treatment of the disc started in 1963 with Lyman Smith injecting chymopapain in discs. ${ }^{11,12,13}$ In 1977, Hijikata did Percutaneous Manual Discectomy ${ }^{14}$; then in 1984, Ascher did Percutaneous Laser Discectomy (nonspecific depressurization) and in 1985, Onik proposed Automated Percutaneous Lumbar Discectomy (nonspecific disc deflation in the absence of visualization) using a probe and published their work. These methods of pure intradiscal decompression surgery typically gave more effective and faster results as compared to waiting for natural, nonsurgical resolution of the painful condition. ${ }^{15,16}$ Percutaneous discectomy thus started as a "blind" fluoroscopically guided method used for merely intradiscal debulking or volume and pressure reduction of the disc. The surgical goal was mechanical decompression and was blind and fluoroscopically guided as pain was thought to be only due to increased pressure inside the disc and around the root and DRG.

In 1988, Kambin and Sampson described a purely endoscopic visualized technique (full endoscopy (FE) TFE) as an extraforaminal approach, for non-sequestrated intracanal discal hernia. ${ }^{17}$ This technique and its outcomes have evolved with time, including translaminar dorsal access surgery and simultaneous use of an arthroscope through access cannulas. The present day foraminal approach is credited in 1996 to Mathews: Transforaminal Endoscopic Micro discectomy when he emphasized extending intradiscal therapy to decompressing the foramen through an endoscope. Matthews was developing a fiber optic endoscope for Sofamor Danek. ${ }^{18}$ Yeung and Kambin, before Matthew's publication, had already began to use a working channel endoscope by Smith and Nephew, exploring the epidural space, but only the YESS scope was commercialized by Richard Wolf.

In the 1990s, many switched from open discectomy with the naked-eye to microscope assisted discectomy. This refined version of open disc surgery uses the microscope to magnify and visualize the target. Endoscope assisted surgery per Foley, ${ }^{19}$ but developed earlier by Destandau ${ }^{20}$ as a custom endoscope aided system, evolved around 1995 but in all these developments understanding and philosophy did not change with respect to traditional goals of ONLY mechanical disc decompression. Historically, Destandeau preceded Foley although Foley published first. This may be labelled as early period of the TFE.

It was in 1991 that Kuslich first described surgery for lumbar disc herniation and stenosis under progressive local anesthesia in 193 patients. This study made an important contribution to our understanding of tissue origin of low back pain and sciatica and gave us the concepts of pain generators, pain patterns by answering the fundamental question: where is the pain coming from $?^{21}$ Thus identifying the physiological target. This also fundamentally made surgery possible under local anesthesia as significant pain was not seen in paraspinal structures during transforaminal access. Another important conceptual change around that time (1995) was a study of foraminal anatomy and its relation to size of cannulas that the foramen can accept. A study by Mirkowitz supervising his then resident David Swartz, highlighted the maximum size of cannulas which we can safely put in the foramen for safe endoscopic surgery. ${ }^{22}$ This facilitated transforaminal access. TFE really started changing around this time. 
In the same period, Siebert: Endoscopic Laser Disc Surgery - the Foraminal Approach, Leu: Percutaneous Foraminoscopy, and Casper : Foraminal Laser Endoscopic Disc Ablation published their work. Martin Knight around same time, ${ }^{23,24,25,26}$ however, was the first to use laser for foraminal decompression for lateral and subarticular stenosis, which further set the stage for Yeung's evolution of his technique for inside out disc surgery and surgery for foraminal stenosis, using a combination of laser and mechanical trephines, kerrisons, and burrs by working outside the disc through a working channel endoscope. Yeung was already proficient with the transforaminal approach developed by Kambin, which emphasized decompression of the epidural space indirectly, and avoiding the epidural space in order to spare its vasculature and theoretically avoid scarring. The access then evolved further as a direct epidural access by undercutting the facet by "outside in access". This has been popularized by Hoogland et al's Thessys technique. ${ }^{27,28,29,30}$ Some variation in trajectory and angle of access also has been proposed by Hoogland, Ruetten and Choi, et al. when targeting inferior and superior migrated fragments. This targeted entry, which can vary from extreme lateral from the midline to a more moderate 35-45 degree angle, and is directed to traverse the foramen toward the disc extrusion or osteophyte. Since the "out-side in" procedure is partially blind and dependent on serial dilation to retract nerves, it usually involves foraminalplasty with trephines and reamers as well as discectomy. While this approach is better understood by traditional surgeons using dilation techniques for MIS surgery, this simplified approach ignores anomalous anatomy such as furcal nerves, sympathetic nerves and other and anomalous nerves documented and described by Yeung and Gore. Complications and adverse risks of dysesthesia is therefore anticipated to be higher. Ruetten has also described interlaminar access with the same instruments, mainly for L5-S1 access.

\section{Pathologies visualized through scope and conditions ideal for the transforaminal approach}

An inflammatory membrane is identified in the epidural space containing multiple nerves entering the disc through a grade $\mathrm{V}$ annular defect as seen from inside by an endoscope (Figure 17). Illustration of a Grade IV Annular tear. Annular tears can be graded according to Adam's Classification. It can be visualized intradiscally and treated with tools utilizing bipolar flextip Radiofrequency, laser, tissue sealants, and biologics that enhance tissue healing. 

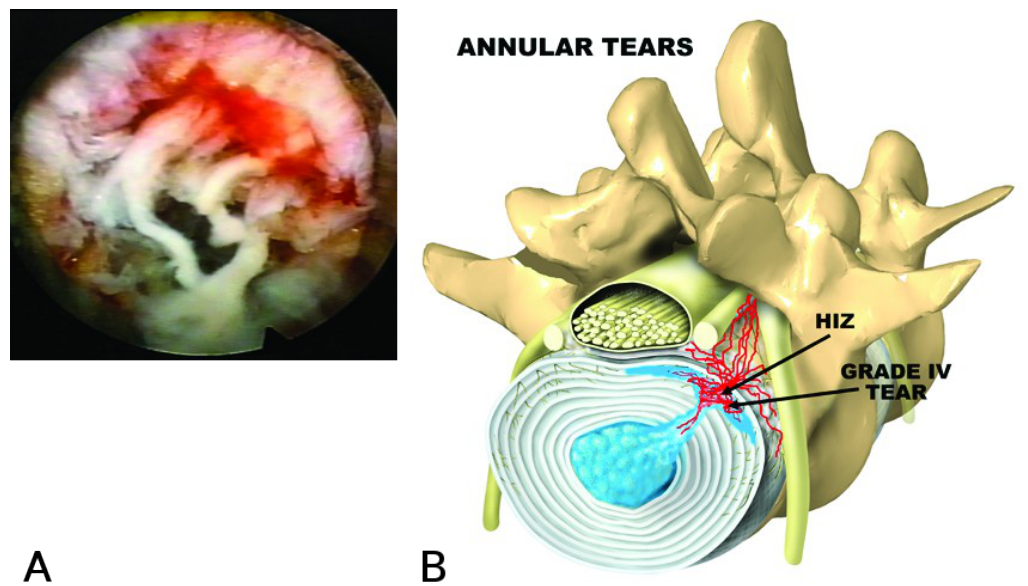

A

B

Fig. 17. Annular tears.

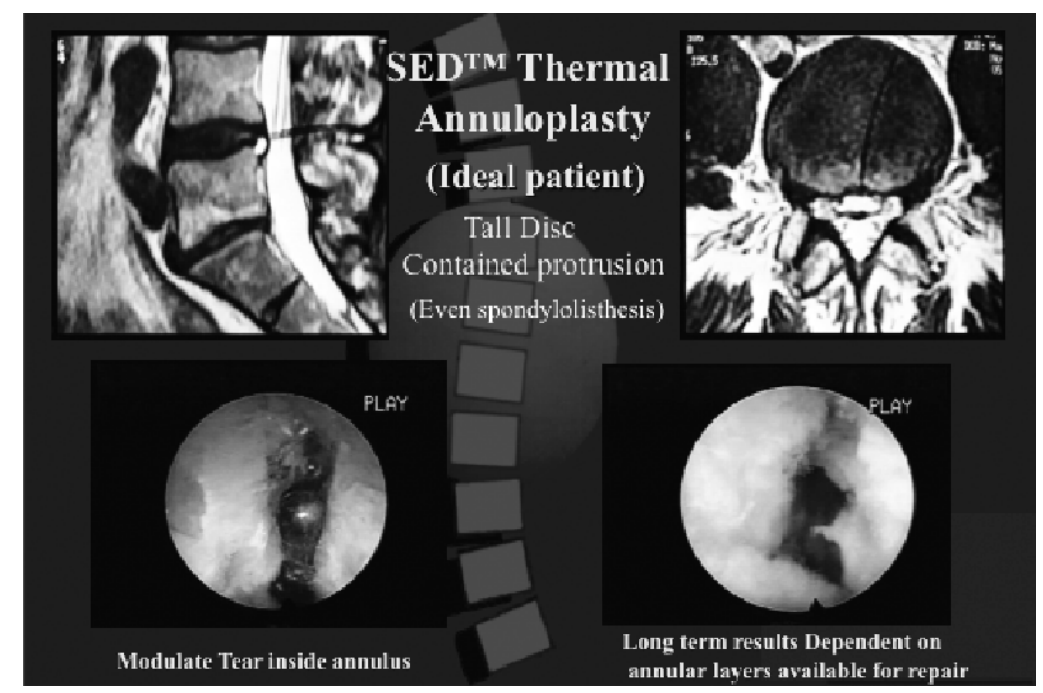

Fig. 18. Radiofrequency Thermal Modulation of a Grade IV annular tear in a tall disc.

Intraoperative PA and lateral discogram demonstrating a grade $\mathrm{V}$ annular tear (Figure 19A-E). Annular defect identified after removing the degenerative nucleus. The defect was visualized with a 70-degree scope. The nerve and dura was protected by an intact PLL between the annular defect and epidural space, shielding the nerve from chemical irritation. The tear would open and close with the patient's breathing. The nerve and epidural space was shielded by the PLL. Note mildly inflamed disc annulus and blue stained nucleus material (Figure 19F). Thermal modulation with a bipolar flex probe (using a biportal technique) ablated the inflammatory and disc tissue and partially contracted the hole in the annulus (Figure 19G). After thermal modulation, a valve-like flap would open and close the hole (Figure 19H). Discectomy specimen contained 4 grams of soft, degenerative nucleus pulposus. This patient remains asymptomatic after 5 years. 

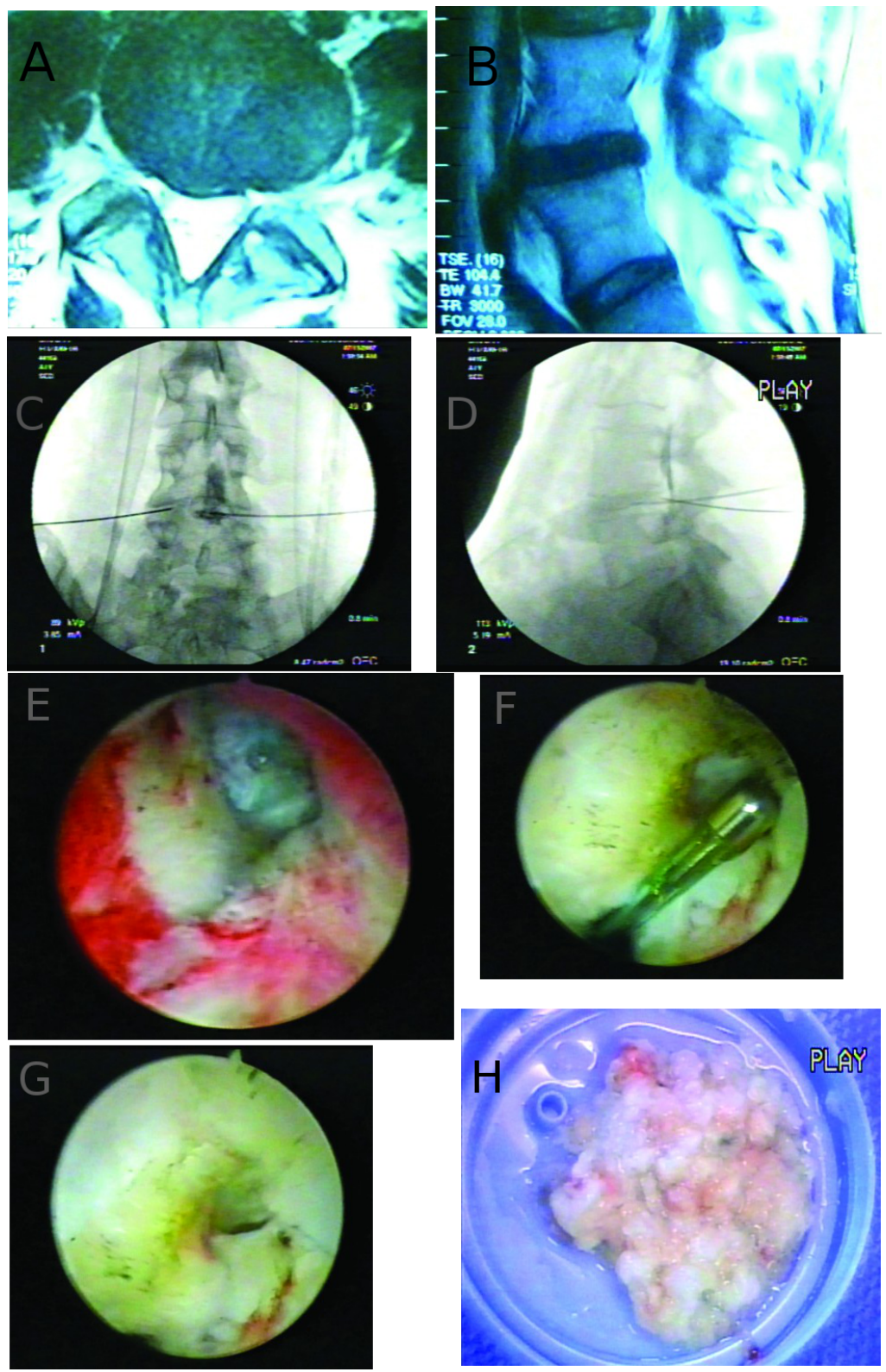

Fig. 19.

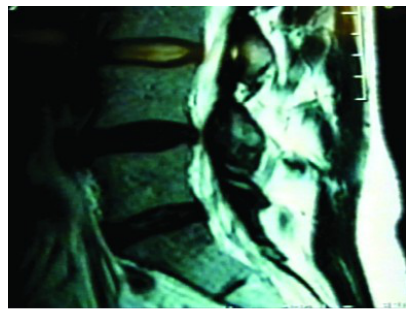

A

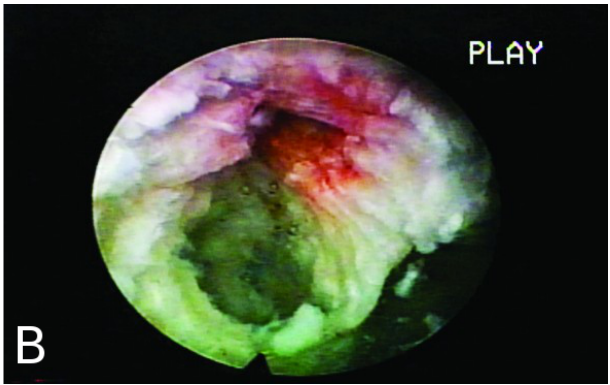

Fig. 20. A: This saggital MRI demonstrates two dark discs on T2 imaging, but does not show significant disc protrusion or the presence of an HIZ. It could be interpreted as "normal." Positive evocative discography identified a painful grade IV annular tear. B: The annular tear is identified endoscopically and successfully treated with foraminal discectomy and thermal annuloplasty. 


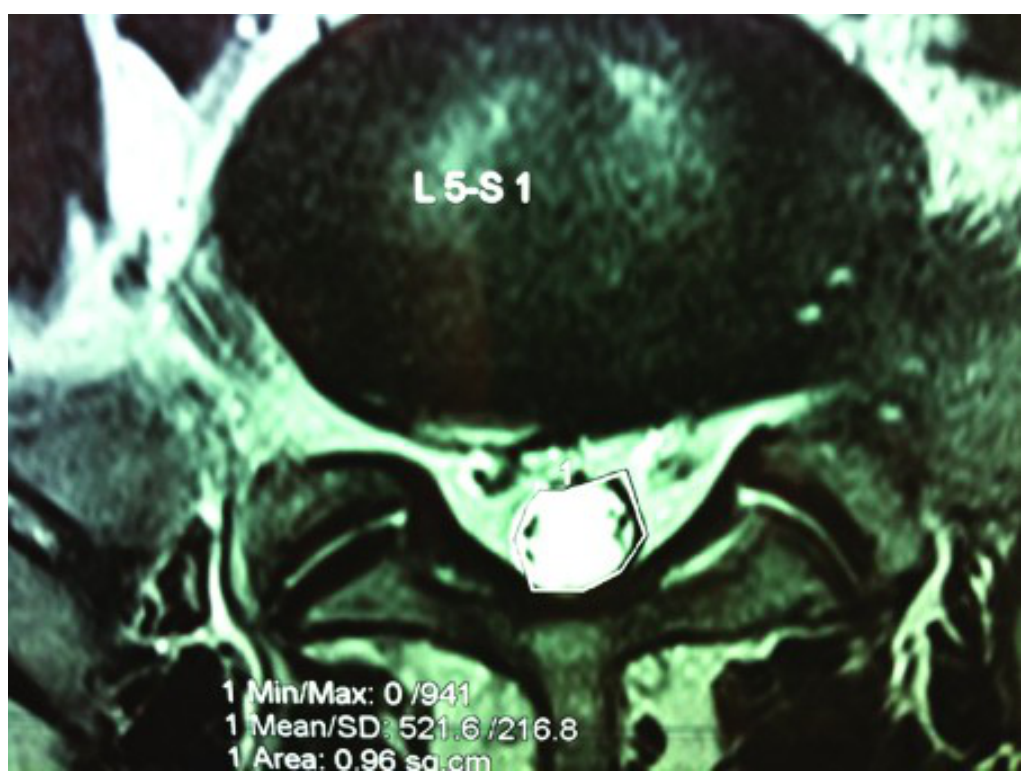

Fig. 21.

This MRI demonstrates a bulging disc with an annular tear that progressed to in an eventual herniation. The patient had intermittent, but debilitating pain at this stage. Earlier definitive treatment of this condition with Disc FX or selective endoscopic discectomy would have mitigated the years of prolonged and debilitating symptoms (Figure 22). The patient progressed to herniation without radiculopathy initially. Back pain and sciatica later on was constant. An extruded free fragment was found at surgery. 


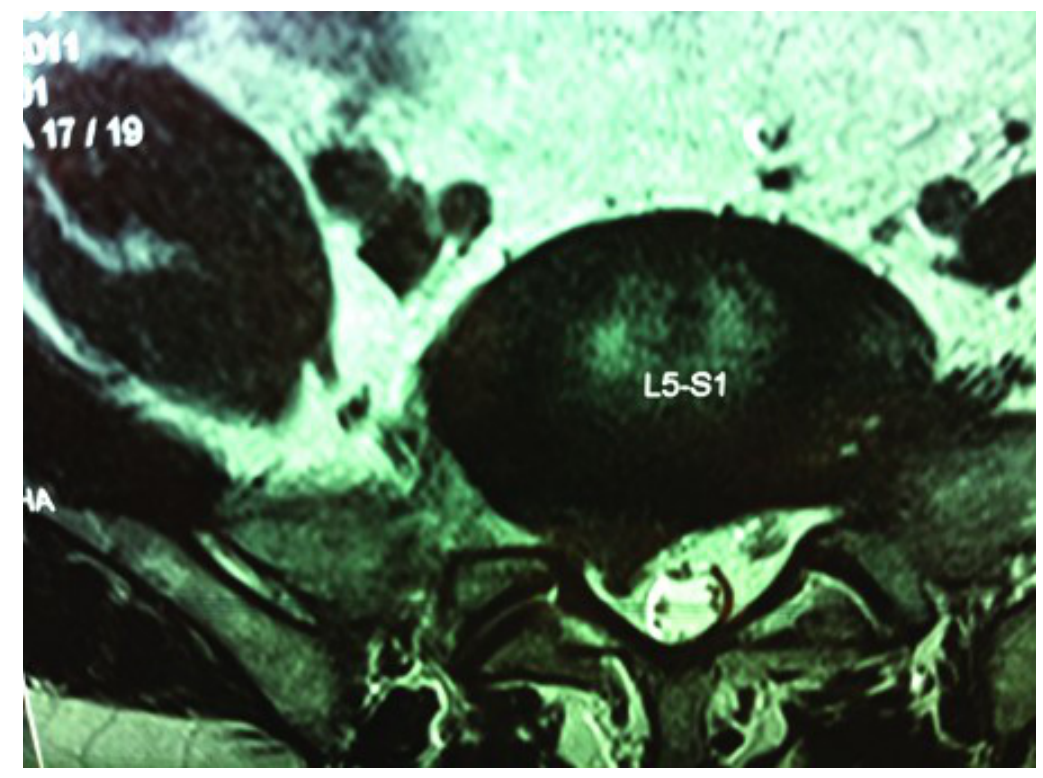

Fig. 22.

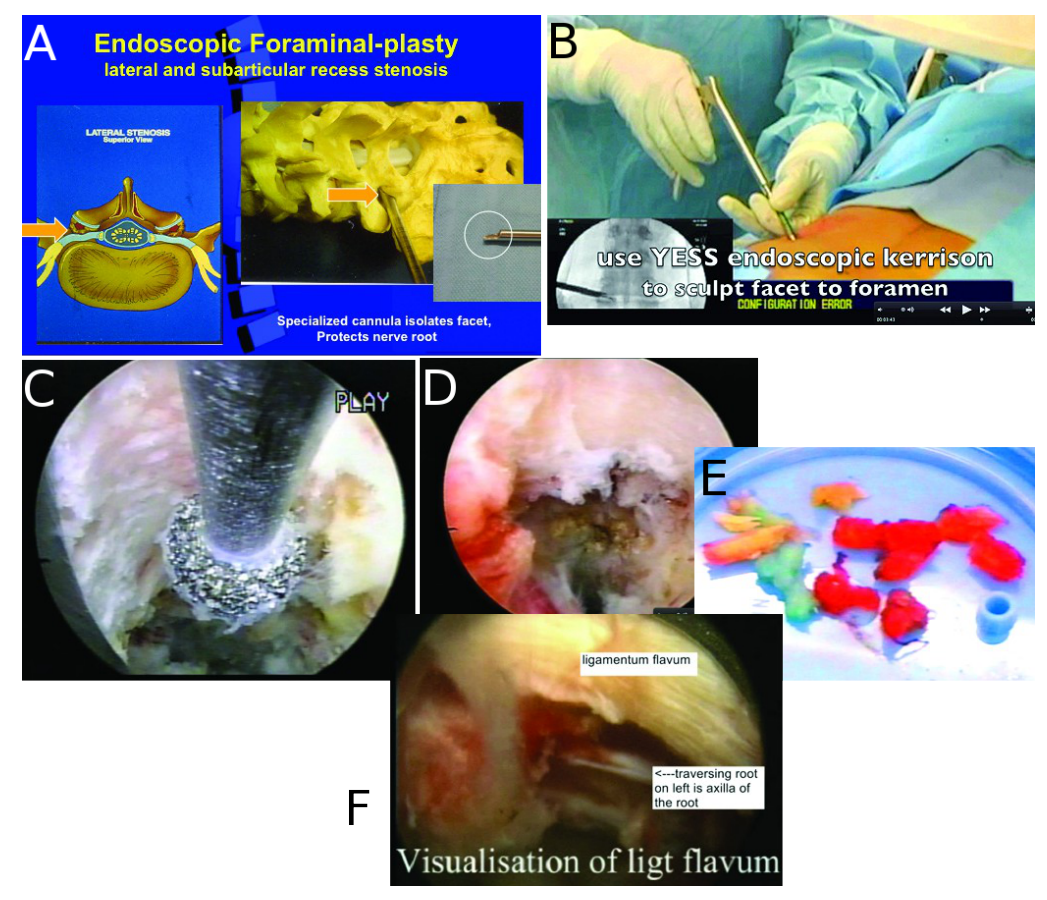

Fig. 23. A. Cannula placement for foraminalplasty. B. Kerrison foraminoplasty. C.

Diamond burr decompressing ventral aspect of the SAP. D. Relationship of the exiting nerve with the SAP. E. Bony specimen and foraminal disc fragment removed following foraminoplasty. F. The ligamentum flavum seen well. 

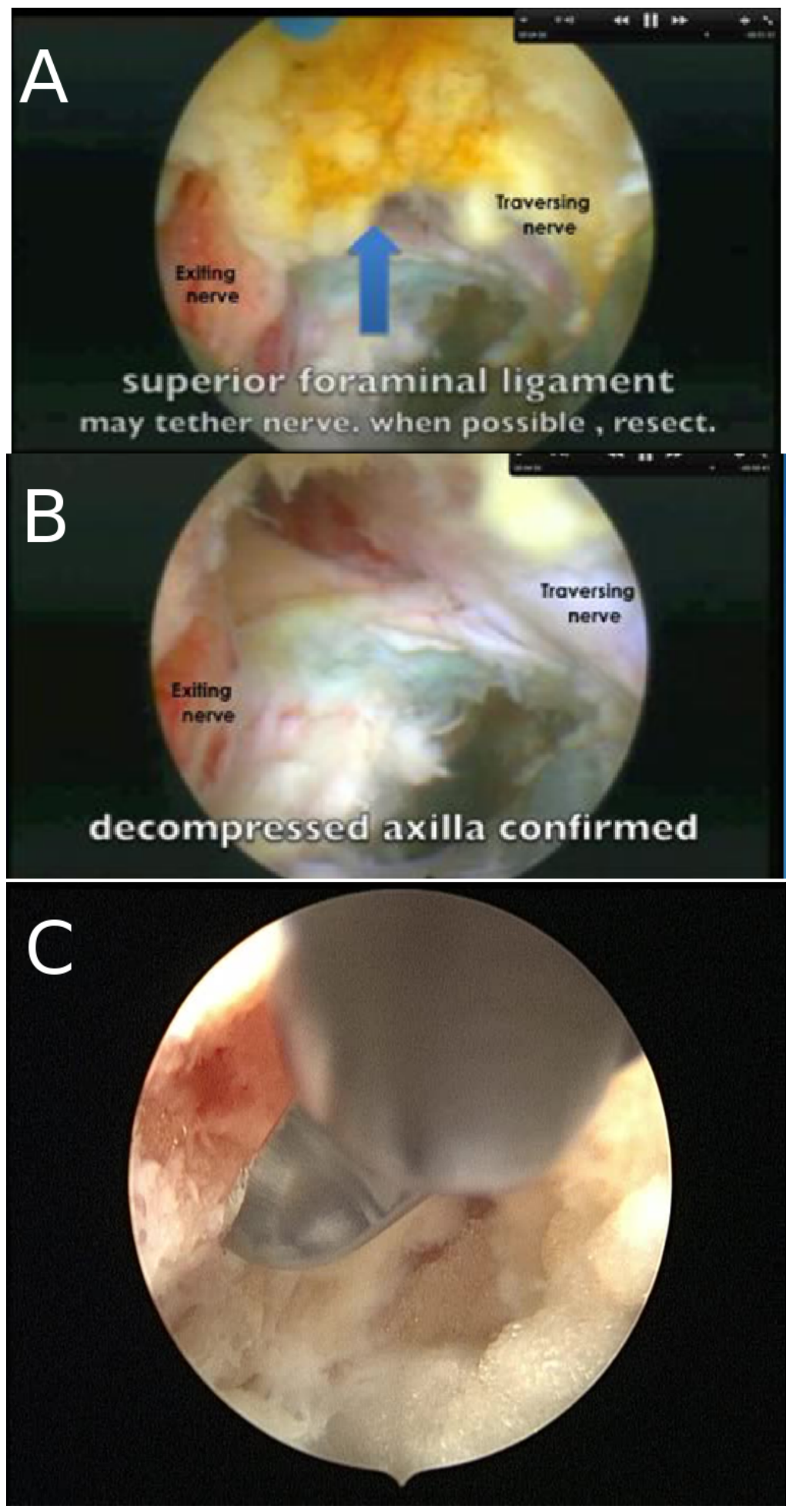

Fig. 24.

The newer emphasis is on cases of FBSS where we can now visualize the hidden zone of Mcnab and relieve the likely common cause of failure by decompressing the axilla between the traversing and exiting nerve (Figure 24). Patho-anatomy such as recurrent/ residual HNP, lateral stenosis, ostephytosis, synovial cysts have all been identified in the absence of obvious abnormal MRI and CT scan imaging. Imaging studies in this "pain 
generating" region do not always have clear findings. The application of diagnostic and therapeutic injections performed by the operating MIS surgeon will provide a prognosis for this type of decompression without "burning any bridges for subsequent more traditional decompression and fusion. ${ }^{31,32}$

Advantages of TFE access and surgery:

1. Muscle trauma: Wolfgang Rauschning's work on the macro-and micro-anatomy of degenerative disc disease, and the importance of preserving the dorsal muscle column serves as a guide for the ideal minimal approach in the lumbar spine. $\left({ }^{31}\right)$ Postsurgical specimens of patients who had posterior lumbar surgery all have extensive scar formation of the dorsal column muscles, even with smaller incisions. According to Rauschning, not only were the erector spinae muscles affected, but so were the deep short oligosegmental muscles which account for proprioception and fine tuning of segmental mobility. Rauschning concluded that surgery should avoid traumatizing the dorsal muscle column.

2. In the transcanal approach, surgeon is limited with exposure, he is also limited by the approach itself. Resection of lamina, ligamentum flavum, and annulus may be necessary to reach the herniation, thus potentially destabilizing the spinal segment. Even after reaching the herniation site, the surgeon still cannot see inside the disc to inspect for residual fragments. In the TFE approach there is no destabilization and no access related morbidity but we can see inside of the disc well. IN cases of central disc herniation it may very easy to target and remove a central herniated contained protrusion or fragment by transforaminal access staying inside the disc. $\left({ }^{3}\right)$ Further, the translaminar approach does not allow the surgeon to visualize the nucleus inside the disc in order to determine if all of the loose nuclear tissue was removed. This is important to prevent early recurrence. The extent of nucleus removal remains unresolved among traditional surgeons utilizing the posterior approach. Some surgeons remove only the disc sequestrum and others remove all the disc they can extract through the annulotomy site. Surgeon philosophy dictates the technique that is followed.

3. Annular tears come in all sizes and shapes. Granulation tissue in annular defects (tears) can be visualized and ablated and closed using a RF electrode. It is best identified by discography, not always on MRI. Endoscopy can successfully identify and treat painful annular tears and is much more effective than the image guided techniques of IDET and variations of surgical disc decompression.

4. Selective nerve root block and epidurography is performed by the surgeon, and can be considered a pre-surgical trial that provides prognostic information. $\left.{ }^{32}\right)$ The resulting foramino-gram will then provide the surgeon with additional imaging information by the contrast pattern outlined at the surgical site. This will be anatomical input. A favorable response to interventional therapeutic injections can be correlated with longer term favorable results of foraminal decompression, nerve ablation and disc decompression. Conditions such as foraminal osteophytes tethering the nerve, and lateral recess stenosis are often underestimated by traditional imaging. With diagnostic and therapeutic injections, providing additional information about the pain generator, both surgeon and patient can come to an informed joint decision with respect to determining the likelihood of surgical success. This is especially true given that surgery of discectomy can be combined with foraminal decompression and 
ablation, making it more likely that the surgeon will be able to remove the source of pain.

5. The learning curve may be steep ${ }^{33}$ but once the technique is mastered, the surgeon is able to extract contained and non-contained disc herniation from within the disc or directly from the epidural space.

6. The Holmium-YAG laser, in a straight fiber or a reflected 70 degree fiber has the unique ability to divide shrink, ablate, and cut collagenous tissue and vaporize bone.

7. The foraminal approach is more versatile than the posterior approach, the more cephalad the herniation level. From T-10 to L-2, the foraminal posterolateral approach offers the greatest and most flexible access to the lumbar disc without the need for laminectomy.

8. In surgical discectomy by any approach, the paradoxical effect of nucleus pulposus removal and the amount of postoperative instability created by removing and decompressing the disc should be considered by the surgeon. Annular fenestration has been studied, ranging from dilation of the annulus to cutting out an annular window. In most instances, a sharp annulotomy knife or trochar is used to perform, at minimum, a cruciate incision. It will be necessary to remove the hernia at its weakest point during a transcanal approach, weakening the annulus further and making it more susceptible for a recurrent herniation.

9. Foraminoplasty: IN comparison to trans laminar decompression, there is less instability produced by decompression, as the articular surface area of the facet joints are preserved.(34) More widening is achieved by transforaminal access in a case of stenotic lateral canal than by a medial facetectomy, which adds instability too.

10. Transforaminal and translaminar endoscopy access inherently avoids excessive removal of ligamentum flavum in the interlaminar area. IT may be important to retain that barrier between dura and muscles. Our technique preserves ligamentum flavum and that is significant in preventing scar formation. (35)

11. Visualization A: has been touted as an important factor by traditional surgeons in choosing their method of disc excision. Most who are familiar with the microscope tout it as being un-surpassed for visualization, emphasizing the 3-Dimensional capability of binocular vision, as the best visualized technique. For teaching purposes, the assistant can also see. With the new glass rod-lens endoscopes, however, it only requires side-by-side comparison of images to dispel the notion that visualization is inferior. While the microscope is capable of giving great visual detail, the endoscope can match the detail and with magnification as well. In a learning situation, the entire OR crew can see what is happening on the video screen.

12. Visualization B: The advantage of the endoscope is the ability to place the lens and surgical instruments closer to the pathology, which requires less magnification for the same detail. The ability to manipulate the endoscope for viewing the pathology at slightly different angles and varied depths, the ability to manipulate normal and patho-anatomy, and the ability to visualize the disc intradiscally as well as the foramen overcomes any concern about the lack of 3-Dimensional visualization. This happens in a awake and aware patient. Accomplished surgeons have also used the endoscope in all fields of surgery with no problems from the lack of 3-D visualization.

13. Once the learning barriers are overcome, however, surgeons who are competent in both techniques may prefer the posterolateral endoscopic disc surgery to microdiscectomy or micro-endodiscectomy for selected herniations. It is better for the 
patient, has less surgical morbidity, has equivalent results, and will not affect a subsequent posterior surgical approach if needed. Cadaveric-experimental studies comparing the transcanal approach and the foraminal approach clearly showed that both approaches to the lumbar discs carry potential risk for injury or violation of blood vessels and spinal nerves. When a surgeon limits his exposure, there is a learning curve, and complications may arise because of unfamiliarity with the limited surgical view in both techniques.

14. If we consider all these advantages TFE is a matter of choice by default. It can deliver same results with less of morbidity and complications.

\section{A review of the literature}

Looking at studies before $1995,{ }^{36-46}$ we find that surgery was mainly under fluoroscopy and in later years visualized. Annular opening was done after fenestrating the annulus nerve by blunt palpation. Contraindications of those years were sequestrations, calcified or narrow disc, cauda equina syndrome, previous same level surgery, instability, large extra ligamentous disc, high iliac crest, stenosis, listhesis. Over years we have standardized our technique and overcome all contraindications except instability and central canal stenosis. We need to combine TFE with stabilization and in stenosis we may need additional interlaminar surgical access(Table 1).

Table 1. Studies from 1986 to 1995.

\begin{tabular}{|c|c|c|c|c|c|c|c|}
\hline $\begin{array}{l}\text { Study } \\
\text { Authors }\end{array}$ & Inclusion & Exclusion & $\begin{array}{l}\text { Type in most } \\
\text { not known } \\
\text { unless } \\
\text { mentioned }\end{array}$ & Intradiscal & $\begin{array}{l}\text { Follow-up } \\
\text { All followed } \\
\text { up except } \\
\text { where } \\
\text { mentioned }\end{array}$ & Outcome & $\begin{array}{l}\text { Year and } \\
\text { Reference }\end{array}$ \\
\hline $\begin{array}{l}\text { Schreiber } \\
\text { suezawa leu }\end{array}$ & Radiculopathy & 1 & $\begin{array}{l}\mathrm{N}=174 \mathrm{~m} 68 \\
\text { f106 age } \\
\text { 39years [16-81] } \\
\text { multiple level } \\
\mathrm{n}=25\end{array}$ & $\begin{array}{l}+ \text { modified } \\
\text { hijikata } \\
\text { biportal }\end{array}$ & $28 \mathrm{mth}$, & $\begin{array}{l}\text { Gpe s/s score } \\
85 \mathrm{e}+\mathrm{g} \\
\text { Complications } \\
10 \% \\
\text { Reoperation } \\
\text { Rate } 21 \%\end{array}$ & $\begin{array}{l}\text { 1986; 1988; } \\
1991^{36,37,38,39}\end{array}$ \\
\hline Savitz & $\begin{array}{l}\text { Radiculopathy, } \\
\text { tension signs, neuro } \\
\text { deficit }\end{array}$ & 1,4 obese & $\begin{array}{l}\mathrm{N}=300 \mathrm{~m} 132 \mathrm{f} \\
16816-81 \text { years } \\
\text { multilevel } \mathrm{n}=40 \\
\mathrm{~L} 2-\mathrm{S} 1\end{array}$ & $\begin{array}{l}\text { + Kambin } \\
\text { technique }\end{array}$ & 6 months & $\begin{array}{l}\text { Return to } \\
\text { work at } 6 \\
\text { months } 67 \% \\
\text { Complications } \\
5.3 \% \\
\text { Reoperation } \\
\text { Rate } 1.3 \%\end{array}$ & $\begin{array}{l}40,411994, \\
1999\end{array}$ \\
\hline $\begin{array}{l}\text { Mayer and } \\
\text { brock }\end{array}$ & $\begin{array}{l}\text { Radiculopathy, } \\
\text { tension signs, neuro } \\
\text { deficit }\end{array}$ & $1,3,4,5,8,9$ & $\begin{array}{l}\mathrm{N}=30 \text { m11 f } 19 \\
\text { multi level n=1 } \\
\text { L2-L5 }\end{array}$ & +peld & 6-18 months & $\begin{array}{l}\text { Gpe s/s scope } \\
67 \\
\text { e+g } 33 \\
\text { moderate or } \\
\text { poor [inclu } \\
\text { reop] } \\
90 \% \text { returned } \\
\text { to work at } 6 \\
\text { months in } \\
7.1+-4.2 \text { wks } \\
\text { Complications } \\
3.3 \% \\
\text { Reoperation } \\
\text { Rate } 3.3 \%\end{array}$ & $1993^{42}$ \\
\hline
\end{tabular}




\begin{tabular}{|c|c|c|c|c|c|c|c|}
\hline Ditsworth & $\begin{array}{l}\text { Radiculopathy, } \\
\text { tension signs, } \\
\text { instability Flexible } \\
\text { endoscope }\end{array}$ & 5,8 & $\begin{array}{l}\mathrm{N}=110 \mathrm{~m} 40 \mathrm{f} \\
70 \\
55 \text { years[20-65] } \\
\text { all ldh } \\
\text { single level }\end{array}$ & $\begin{array}{l}+ \text { and } \\
\text { ic too }\end{array}$ & $24-48$ months & $\begin{array}{l}\text { Gpe } 91 \text { exe } \\
+\mathrm{g} \\
4.5 \text { poor } \\
\text { rec } 0 \\
\text { Complications } \\
0.9 \% \\
\text { Reoperation } \\
\text { Rate } 4.5 \%\end{array}$ & 431998 \\
\hline Hag & $\begin{array}{l}\text { Radiculopathy } \\
\text { neurodeficit Sofamor } \\
\text { danek system }\end{array}$ & 2 & $\begin{array}{l}\mathrm{N}=101 \\
\text { all ldh } \\
\text { single level } \\
\mathrm{L} 2 \mathrm{~S} 1 \\
3 \text { exclu as } \\
\text { procedures had } \\
\text { intraop problem }\end{array}$ & + & $\begin{array}{l}28 \\
\text { months[15-26] } \\
9 \text { did not } \\
\text { respond }\end{array}$ & $\begin{array}{l}\text { ps: good } 66 \\
\text { satisfied } 9 \\
\text { poor } 25 \\
\text { Complications } \\
7.6 \\
\text { Reoperation } \\
\text { Rate } 17\end{array}$ & $1999^{44}$ \\
\hline Hochschuller & $\begin{array}{l}\text { Radiculopathy AMD } \\
\text { kambin method }\end{array}$ & $1,4,7$ & $\begin{array}{l}\mathrm{N}=18 \mathrm{~m} 5 \mathrm{f} 13 \\
31 \text { years[18-55] } \\
\text { L3-S1 }\end{array}$ & + & $\begin{array}{l}9 \text { months } \\
\text { [4-13] }\end{array}$ & Reop $11 \%$ & $1991^{45}$ \\
\hline Kambin & $\begin{array}{l}\text { Radiculopathy } \\
\text { tension signs, deficit } \\
\text { AMD Kambin } \\
\text { technique biportal } \\
\mathrm{n}=59\end{array}$ & $3,4,6$ & $\begin{array}{l}\mathrm{N}=175 \mathrm{~m} 76 \mathrm{f} \\
99 \\
\text { all ldh } \\
\text { single level } \\
\text { L2-S1 }\end{array}$ & + pure & $\begin{array}{l}48 \text { months } \\
{[24-78]} \\
3.4 \text { did not } \\
\text { respond }\end{array}$ & $\begin{array}{l}\text { GPE [mod } \\
\text { presby st.luke } \\
\text { score] } \\
77 \text { exc } 11 \\
\text { good } \\
12 \text { failed } \\
\text { return to work } \\
3 \text { weeks } 95 \% \\
\text { Complications } \\
5.3 \\
\text { Reoperation } \\
\text { Rate } 7.7\end{array}$ & $1992^{46}$ \\
\hline
\end{tabular}

key: sequestrations[1], calcified or narrow disc[2], cauda equina syndrome[3], previous same level surgery[4], instability[5], large extra ligamentous disc[6], high iliac crest[7], stenosis[8], listhesis[9].

There are 15 studies during the period from 1995 to $2005 .{ }^{47-59}$ This was a time when spine endoscopy was in flux and evolving, after the YESS system received FDA approval in 1998. A study focusing on identification of pain generators 1991, and the anatomy of the foramen in 1995 were published with studies supporting and validating these ideas and mainly standardizing the instruments. Even though there were not many randomized controlled trials, first prospective randomized controlled trial was published by Hermantin et al in 1999 and a sound and strong base was created for taking these ideas further by adding many other complementary technologies like RF, laser and improvements in optics and surgical instruments. It was established that without any posterior midline access we could deliver same or better results. It also established precision needed for adoption of the technique. The indications and inclusions have changed to include sequestrations, prior surgery and even nerve deficits. The exclusions have narrowed. The reoperation rates are around 5\% and complications are low. The surgery has now essentially become intra and extradiscal, and use of YESS system has become common by 2005 (Table 2 ). 
Table 2. Studies from 1995 to 2005.

\begin{tabular}{|c|c|c|c|c|c|c|c|}
\hline $\begin{array}{l}\text { Study and } \\
\text { author }\end{array}$ & Indication & Exclusion & $\begin{array}{l}\text { Total, sex } \\
\text { distribution, age, } \\
\text { type where } \\
\text { known, levels }\end{array}$ & $\begin{array}{l}\text { Intra and } \\
\text { extradiscal }\end{array}$ & $\begin{array}{l}\text { Followup } \\
\% \\
\text { nonresponsive }\end{array}$ & $\begin{array}{l}\text { Results on GPE } \\
\text { or Mcnab, } \\
\text { excellent, poor, } \\
\text { recurrence, } \\
\text { complications, } \\
\text { reoperative } \\
\text { NK is "not } \\
\text { known" }\end{array}$ & $\begin{array}{l}\text { Year and } \\
\text { reference }\end{array}$ \\
\hline $\begin{array}{l}\text { Yeung and } \\
\text { Tsou }\end{array}$ & $\begin{array}{l}\text { Prior disc } \\
\text { surgery } n=31 \\
\text { radiculopthy } \\
\text { neuro deficit }\end{array}$ & 1,8 & $\begin{array}{l}\text { All herniations } \\
\mathrm{n}=307 \mathrm{~m} 102 \mathrm{f} \\
205 \text { age } 18-72 \\
\text { Singles } \\
12 \text { to s1 }\end{array}$ & + yess RW & $\begin{array}{l}\text { Mean } 19 \\
\text { months } 8.8 \% \\
\text { non } \\
\text { responders }\end{array}$ & $\begin{array}{l}\text { Macnab } 84 \\
\text { poor } 9.3 \% \text { rec } \\
0.7 \% \\
\text { complic1ations } \\
3.9 \\
\text { Reoperation } \\
\text { Rate } 4.6\end{array}$ & $2002^{47}$ \\
\hline Wojcik & Radiculopathy & 1, ddd & $\mathrm{N}=43 \mathrm{~m} 25 \mathrm{f} 18$ & $\begin{array}{l}\text { intra hijikata } \\
\text { method }\end{array}$ & $\begin{array}{l}18 \text { months } \\
16.3 \% \\
\text { nonresponders }\end{array}$ & $\begin{array}{l}\text { GPE } 64 \text { good } \\
36 \text { satisfied } 0 \\
\text { poor } \\
\text { Complications } \\
\text { NK } \\
\text { Reop NK }\end{array}$ & $2004^{48}$ \\
\hline $\begin{array}{l}\text { Tsou and } \\
\text { Yeung }\end{array}$ & $\begin{array}{l}\text { Radiculopathy } \\
\text { neurodeficit }\end{array}$ & 1,4 & $\begin{array}{l}\text { N219 m83 f } 136 \\
\text { age } 42[17-71] \\
\text { Central ldh } \\
\text { single level } \\
\text { L3S1 }\end{array}$ & $\begin{array}{l}+ \\
\text { yess } \\
\text { rw }\end{array}$ & $\begin{array}{l}20 \text { months } \\
{[12-108] 11.9} \\
\text { non resp }\end{array}$ & $\begin{array}{l}\text { Gpe } 91 \mathrm{e}+\mathrm{g} \\
\text { poor } 5.2 \mathrm{rec} 2.7 \\
\text { Complications } \\
2.7 \\
\text { Reoperation } \\
\text { Rate } 4.6\end{array}$ & $2002^{3}$ \\
\hline Lew & $\begin{array}{l}\text { Radiculopathy } \\
\text { tension signs } \\
\text { neuro deficit }\end{array}$ & 4 & $\begin{array}{l}\mathrm{N}=47 \mathrm{~m} 12 \mathrm{f} 35 \\
51 \text { years[30-70] } \\
\text { foraminal } \\
\text { exforaminal } \\
\mathrm{L} 1-\mathrm{L} 5 \\
+ \text { ped }\end{array}$ & $\begin{array}{l}\text { Surgical } \\
\text { dynamics } \\
\text { system }\end{array}$ & $\begin{array}{l}18 \text { months } \\
{[4-51]}\end{array}$ & $\begin{array}{l}\text { GPE } 85 \text { e and g } \\
11 \text { poor return } \\
\text { to work } 89 \% \\
\text { Complications } \\
0 \\
\text { Reoperation } \\
\text { Rate } 11\end{array}$ & $2001^{49}$ \\
\hline Hoogland & $?$ & $?$ & $\mathrm{~N}=246 \mathrm{nk} \mathrm{nk}$ & $\begin{array}{l}\text { Extra Thessys } \\
\text { system }\end{array}$ & 24 months & $\begin{array}{l}\text { Gpe } 86 \% \text { exc }+ \\
\mathrm{g} \\
7.7 \text { poor } \\
\text { Complications } \\
1.2 \\
\text { rec } 3.5 \text { [ } 1 \text { year] }\end{array}$ & $2003^{50}$ \\
\hline Eustacchio & $\begin{array}{l}\text { Radiculopathy, } \\
\text { tension signs } \\
\text { neuro deficit }\end{array}$ & 3 & $\begin{array}{l}\mathrm{N}=122 \mathrm{~m} 36 \mathrm{f} 86 \\
55 \text { years [18-89] } \\
\text { all ldh } \\
\text { multilevel } \mathrm{n}=4 \\
\mathrm{~L} 2-\mathrm{S} 1 \\
10 \text { exclu as } \\
\text { stopped } \\
\text { procedures but } \\
\text { here we reviewed }\end{array}$ & intra & $\begin{array}{l}35 \\
\text { months[15-35] }\end{array}$ & $\begin{array}{l}\text { Gpe } 45 \text { exe } 27 \\
\text { good } \\
27 \text { poor } \\
\text { prolo } 71.9 \% \\
\text { exe+good } \\
\text { retrun to work } \\
94 \\
\text { rec } 12 \\
\text { Complications } \\
9 \\
\text { Reoperation } \\
\text { Rate } 27\end{array}$ & $2002^{51}$ \\
\hline Chiu & $\begin{array}{l}\text { Virgin and prior } \\
\text { disc surgery } \\
\text { pain in back, } \\
\text { radiculopathy, } \\
\text { neuro deficit }\end{array}$ & 3 & $\begin{array}{l}\mathrm{N}=2000 \mathrm{~m} 990 \mathrm{f} \\
101044 \text { years } \\
{[24-92] \text { single }} \\
\text { multiple level type } \\
\text { nk stenosis and } \\
\text { ddd included }\end{array}$ & $\begin{array}{l}\text { Intra and } \\
\text { KARL STORZ } \\
\text { eq TF MEAD }\end{array}$ & $\begin{array}{l}42 \text { months } \\
{[6-72-}\end{array}$ & $\begin{array}{l}\text { GPE } 94 \text { exc }+\mathrm{g} \\
3 \text { poor } \\
\text { Complications } \\
1 \\
\text { Reoperation } \\
\text { Rate nk }\end{array}$ & $2004^{52}$ \\
\hline
\end{tabular}




\begin{tabular}{|c|c|c|c|c|c|c|c|}
\hline Ahn & $\begin{array}{l}\text { Prior disc } \\
\text { surgery, tension } \\
\text { signs, neuro } \\
\text { deficit, } \\
\text { radiculopathy }\end{array}$ & $2,5,9$ & $\begin{array}{l}\mathrm{N}=43 \mathrm{~m} 11 \mathrm{f} 32 \\
46 y e a r s[22-72 \text { all } \\
\text { rec after } 6 \text { months } \\
\text { of } \\
\text { microdiscectomy } \\
\text { L3S1 }\end{array}$ & Intra and Peld & 24-39 months & $\begin{array}{l}\text { VAS } 8.7 \text { to } 2.6 \\
\text { diff } 70 \% \text { GPE } \\
28 \text { exc } 63 \text { good } \\
4.7 \text { poor } \\
\text { Complications } \\
4.6 \\
\text { Reoperation } \\
\text { Rate } 2.3\end{array}$ & $2004^{53}$ \\
\hline Suess & $\begin{array}{l}\text { Radiculopathy } \\
\text { deficit }\end{array}$ & 3,8 & $\begin{array}{l}\mathrm{N}=25 \mathrm{~m} 11 \mathrm{f} 14 \\
48 \text { years }[26-72] \\
\text { foraminal }+ \text { exF } \\
\text { single level L2-L5 }\end{array}$ & $\begin{array}{l}\text { PTFES } \\
\text { sequestrectomy }\end{array}$ & 6 weeks & $\begin{array}{l}\text { Pain leg vas } 6.7 \\
\text { to } 0.8 \text { diff } 88 \% \\
\text { pain back } 5.1 \text { to } \\
1.3 \text { diff } 75 \% \\
\text { Complications } \\
4 \\
\text { Reoperation } \\
\text { Rate } 8 \%\end{array}$ & $2005^{54}$ \\
\hline $\begin{array}{l}\text { Schubert and } \\
\text { hoogland }\end{array}$ & $\begin{array}{l}\text { Radiculopathy, } \\
\text { tension signs, } \\
\text { deficit, } \\
\text { sequestration }\end{array}$ & 4 & $\begin{array}{l}\mathrm{N}=558 \mathrm{~m} 179 \mathrm{f} \\
37944 \text { years } \\
{[18-65 \text { all ldh }} \\
\text { single level L2S1 }\end{array}$ & $\begin{array}{l}\text { Intra and } \\
\text { Thessys } \\
\text { system }\end{array}$ & $\begin{array}{l}12 \text { months } \\
8.7 \text { non resp }\end{array}$ & $\begin{array}{l}\text { Pain leg } 8.4 \text { to } \\
1 \text { diff } 88 \% \text { pain } \\
\text { back } 8.6 \text { to } 1.4 \\
\text { diff } 84 \% \\
\text { GPE } 51 \text { exc } 43 \\
\text { good } \\
0.3 \text { poor } \\
\text { rec } 3.6 \\
\text { Complications } \\
0.7 \\
\text { rec } 3.6\end{array}$ & $2005^{55}$ \\
\hline Ruetten & $\begin{array}{l}\text { Radiculopathy } \\
\text { deficit }\end{array}$ & $1,4,8$ & $\begin{array}{l}\mathrm{N}=517 \mathrm{~m} 277 \mathrm{f} \\
24038 \\
\text { years[16-78] all } \\
\text { ldh multiple level } \\
\mathrm{n}=46 \text { L1-L5 }\end{array}$ & $\begin{array}{l}\text { Intra and RW } \\
\text { elted extreme } \\
\text { lateral transf } \\
n=27 \text { bilateral }\end{array}$ & $\begin{array}{l}12 \text { months } \\
10 \text { non resp }\end{array}$ & $\begin{array}{l}\text { pain leg } 7.1 \text { to } \\
0.8 \text { diff } 89 \% \\
\text { pain back } 1.8 \text { to } \\
1.6 \text { diff } 13 \% \\
\text { ODI } 78 \text { to } 20 \\
\text { diff } 74 \% \text { rec } \\
6.9 \\
\text { Complications } \\
0 \\
\text { Reoperation } \\
\text { Rate } 6.9\end{array}$ & $2005^{56}$ \\
\hline Ramsbacher & $\begin{array}{l}\text { Radiculopathy } \\
\text { deficit }\end{array}$ & $1,7,8$ & $\begin{array}{l}\mathrm{N}=39 \mathrm{~m} 21 \mathrm{f} 18 \\
\text { mean age } 50 \text { years } \\
\text { all ldh single level } \\
\text { L3S1 }\end{array}$ & $\begin{array}{l}\text { Intra and } \\
\text { Sofamor danek } \\
\text { TES transf } \\
\text { endo } \\
\text { sequestrectomy }\end{array}$ & 6 weeks & $\begin{array}{l}\text { Pain leg } 6.7 \text { to } \\
0.8 \text { diff } 88 \% \\
\text { pain back5.1 to } \\
1.3 \text { diff } 74 \% \\
\text { ps } 77 \% \text { very } \\
\text { satisfied } \\
\text { +satisfied } \\
\text { Complications } \\
5.1 \\
\text { Reoperation } \\
\text { Rate } 10 \%\end{array}$ & $2000^{57}$ \\
\hline Knight & $\begin{array}{l}\text { Prior surgery } \\
\mathrm{n}=75 \\
\text { back and leg } \\
\text { pain } \\
\text { radiculopathy } \\
\text { Includes DDD } \\
\text { and lateral } \\
\text { stenosis }\end{array}$ & 3 & $\begin{array}{l}\mathrm{N}=25048 \text { years } \\
{[21-86] \text { all ldh }} \\
\text { single multiple } \\
\text { level L2S1 }\end{array}$ & $\begin{array}{l}\text { Intra and ELF } \\
\text { KESS RW }\end{array}$ & $\begin{array}{l}30 \text { months } \\
{[24-48] 3.2} \\
\text { non resp }\end{array}$ & $\begin{array}{l}\text { Pain vas more } \\
\text { than } 50 \% \\
\text { improved } 56 \% \\
\text { ODI } 60 \% \\
\text { improved } \\
\text { Complications } \\
0.8 \% \\
\text { Reoperation } \\
\text { Rate } 5.2 \%\end{array}$ & $\begin{array}{l}1999 \text { and } \\
2001^{15,18}\end{array}$ \\
\hline
\end{tabular}




\begin{tabular}{|c|c|c|c|c|c|c|c|}
\hline $\begin{array}{l}\text { Schenkenbach } \\
\text { and Hoogland }\end{array}$ & $\begin{array}{l}\text { Radiculopathy, } \\
\text { tension signs, } \\
\text { deficit }\end{array}$ & $?$ & $\begin{array}{l}\mathrm{N}=130 \mathrm{~m} 43 \mathrm{f} 87 \\
39 \text { years all ldh } \\
\text { single level L2S1 }\end{array}$ & $\begin{array}{l}\text { Intra and } \\
\text { Thessys } \\
\text { system etd }\end{array}$ & $\begin{array}{l}12 \text { months } \\
5.1 \text { non resp }\end{array}$ & $\begin{array}{l}\text { pain leg diff } 5.9 \\
\text { pain back diff } \\
5.4 \text { GPE } 56 \text { exc } \\
27 \text { good } 6 \text { poor } \\
\text { return to work } \\
6 \text { weeks } 70 \% \\
\text { Complications } \\
1.5 \\
\text { Reoperation } \\
\text { Rate } 4.6 \%\end{array}$ & $\begin{array}{l}1998-99 . \\
28,58\end{array}$ \\
\hline Morgenstern & $\begin{array}{l}\text { Radiculopathy } \\
\text { deficit * study } \\
\text { to compare } \\
\text { normal vs } \\
\text { intense PT } \\
\text { postop } \\
\text { revalidation }\end{array}$ & 1 & $\begin{array}{l}\mathrm{N}=144 \mathrm{~m} 48 \mathrm{f} 96 \\
\text { all ldh multilevel } \\
\mathrm{n}=60 \mathrm{~L} 1 \mathrm{~S} 1\end{array}$ & $\begin{array}{l}\text { Intra and Yess } \\
\text { ess endoscopic } \\
\text { spine surgery }\end{array}$ & $\begin{array}{l}24 \text { months } \\
{[3-48]}\end{array}$ & $\begin{array}{l}\text { GPE m } 83 \text { exc } \\
+ \text { good } \\
3 \% \text { poor } \\
\text { Complications } \\
9 \% \\
\text { Reoperation } \\
\text { Rate } 5.6 \%\end{array}$ & $2005^{59}$ \\
\hline
\end{tabular}

There are 9 significant studies after $2005^{60-68}$ when spine endoscopy was technologically maturing producing relatively consistent results. The inclusion criteria show that we are able to include a vast range of symptoms and degenerative conditions of an aging spine affecting the functional spinal unit. It also identifies where we fall short in patients with instability, central canal stenosis where even today we are in search of complementary solutions. More recent studies in press are addressing instability and failed back surgery syndrome with endoscopic transforaminal fusion and neuromodulation of the Dorsal root ganglion. Spine endoscopy can be done in awake and aware patients thus extending its benefits to medically compromised patients (Table 3 ).

Table 3. Studies 2005-current.

\begin{tabular}{|c|c|c|c|c|c|c|c|}
\hline Author & Inclusion & Exclusion & $\begin{array}{l}\text { Number, } \\
\text { gender } \\
\text { distribution, } \\
\text { age, levels and } \\
\text { type }\end{array}$ & Misc & $\begin{array}{l}\text { Followup and } \\
\text { did not } \\
\text { respond in \% }\end{array}$ & Results & $\begin{array}{l}\text { Year \& } \\
\text { reference }\end{array}$ \\
\hline Tzaan & $\begin{array}{l}\text { Pain in leg and } \\
\text { back }\end{array}$ & $1,2,3,5,8$ & $\begin{array}{l}\mathrm{N}=134 \mathrm{~m} 56 \mathrm{f} \\
78 \\
22-71 \text { years } \\
\text { All ldh } \\
\text { multiple level } \\
\mathrm{n}=2012 \mathrm{~s} 1\end{array}$ & intra+peld & $\begin{array}{l}38 \text { months } \\
{[3-36]} \\
0 \% \\
\text { nonresponders }\end{array}$ & $\begin{array}{l}\text { Gpe } . \text { m. } 28 \text { excellent } 61 \\
\text { good } 3.7 \text { poor } \\
\text { rec } 0.7 \\
\text { Complications } 6 \\
\text { Reoperation Rate } 4.5\end{array}$ & $2007^{60}$ \\
\hline Shim & Radiculopathy & $?$ & $\begin{array}{l}\mathrm{N}=71 \mathrm{~m} 39 \mathrm{f} \\
32 \\
45 \text { years[21-74] } \\
\mathrm{n}=14 \\
\mathrm{~L} 5-\mathrm{S} 1 \\
\text { interlaminar } \\
\text { single level } \\
\text { T12-S1 }\end{array}$ & Intra only & $\begin{array}{l}6 \text { months } \\
{[3-9] 0 \text { non }} \\
\text { resp }\end{array}$ & $\begin{array}{l}\text { Gpe.m } 33 \text { exce } 45 \\
\text { good } \\
6.5 \text { poor } \\
\text { Complications } 2.8 \\
\text { Reoperation Rate } 7 \%\end{array}$ & $2007^{61}$ \\
\hline Jang & Radiculopathy & $4,5,8,9$ & $\begin{array}{l}\mathrm{N}=35 \mathrm{~m} 20 \mathrm{f} \\
15 \\
61 \text { years } \\
\text { [22-84] } \\
\text { foraminal } \\
\text { extraforaminal } \\
\text { single level } \\
\text { L2-S1 }\end{array}$ & $\begin{array}{l}\text { Intra+TPED } \\
\text { system nk }\end{array}$ & $\begin{array}{l}18 \text { months } \\
{[10-35]} \\
0 \text { nonresp }\end{array}$ & $\begin{array}{l}\text { pain vas } 8.6 \text { to } 3.2 \text { diff } \\
63 \% \text { Gpd } 86 \text { exe and g } \\
8.6 \text { poor } \\
\text { rec } 0 \% \\
\text { Complications } 17 \\
\text { Reoperation Rate } 8.6\end{array}$ & $2006^{62}$ \\
\hline
\end{tabular}




\begin{tabular}{|c|c|c|c|c|c|c|c|}
\hline Iprenburg & $\mathrm{Nk}$ & 8 & $\begin{array}{l}\mathrm{N}=149 \mathrm{~m} 62 \mathrm{f} \\
87 \\
43 \\
\text { years[17-82] } \\
\text { all ldh } \\
\text { single level } \\
\text { L3-S1 }\end{array}$ & $\begin{array}{l}\text { Intra+Thessys } \\
\text { system }\end{array}$ & $\begin{array}{l}\text { FU NK } \\
29 \% \text { nonresp }\end{array}$ & $\begin{array}{l}\text { vas nk od nk } \\
\text { rec } 6 \\
\text { Complications or } \\
\text { Reoperation Rate nk }\end{array}$ & $2007^{63}$ \\
\hline Choi & $\begin{array}{l}\text { Radiculopathy } \\
\text { tension signs } \\
\text { neuro deficit }\end{array}$ & $2,4,5,8$ & $\begin{array}{l}\mathrm{N}=41 \mathrm{~m} 23 \mathrm{f} \\
18 \\
59 \text { years[32-74] } \\
\text { extraforaminal } \\
\text { single level } \\
\text { L4-S1 } \\
+ \text { ETF }\end{array}$ & yess & $\begin{array}{l}34 \text { months } \\
{[20-58]} \\
4.9 \text { non resp }\end{array}$ & $\begin{array}{l}\text { pain vas } 8.6 \text { to } 1.9 \text { diff } \\
78 \% \text { return to work } \\
4-24 \text { weeks mean } 6 \\
\text { ODI } 66.3 \text { to } 11.5 \text { diff } \\
83 \% \\
\text { ps } 92 \\
\text { rec } 5.1 \\
\text { Complications } 5.1 \\
\text { Reoperation Rate } 7.7\end{array}$ & $2007^{64}$ \\
\hline Kafadar & $\begin{array}{l}\text { Radiculopathy, } \\
\text { tension signs, } \\
\text { deficit }\end{array}$ & $2,4,5,8$ & $\begin{array}{l}\mathrm{N}=42 \mathrm{~m} 2 \mathrm{f} 40 \\
18-74 \text { years } \\
\text { all ldh } \\
\text { single level } \\
\text { L45 } \\
8 \text { excluded as } \\
\text { procedure } \\
\text { stopped but } \\
\text { inclu here }\end{array}$ & $\begin{array}{l}\text { KARL } \\
\text { STORZ } \\
\text { PETD }\end{array}$ & $\begin{array}{l}15 \text { months } \\
{[6-24]} \\
0 \text { non resp }\end{array}$ & $\begin{array}{l}\text { GPE ss } 14 \text { exc } 36 \text { good } \\
36 \text { poor } \\
\text { rec } 0 \\
\text { Complications } 45 \\
\text { Reoperation Rate } 17\end{array}$ & $2006^{65}$ \\
\hline Hoogland & $\begin{array}{l}\text { Recurrence only; } \\
\text { radiculopathy, } \\
\text { tension signs, } \\
\text { deficit } \\
\text { Patients only with } \\
\text { recurrences after } \\
\text { micro or endo } \\
\text { disc surgery }\end{array}$ & $\mathrm{Nk}$ & $\begin{array}{l}\mathrm{N}=262 \mathrm{~m} 76 \mathrm{f} \\
186 \\
46 \text { years } \\
{[18-80]} \\
\text { all ldh } \\
\text { single level } \\
\text { L2S1 }\end{array}$ & $\begin{array}{l}\text { Intra+Thessys } \\
\text { system }\end{array}$ & $\begin{array}{l}24 \text { months } \\
9 \% \text { non resp }\end{array}$ & $\begin{array}{l}\text { Pain leg } 8.5 \text { to } 2.6 \text { diff } \\
69 \% \text { pain back } 8.6 \text { to } \\
2.9 \text { diff } 66 \% \text { GPE exc } \\
51 \text { good } 35 \\
\text { poor } 5 \\
\text { rec } 6.3 \\
\text { Complications } 1.1 \\
\text { Reoperation Rate } 7\end{array}$ & $2008^{66}$ \\
\hline Sasani & $\begin{array}{l}\text { Radiculopathy, } \\
\text { tension signs, } \\
\text { neurodeficit }\end{array}$ & 4 & $\begin{array}{l}\mathrm{N}=66 \mathrm{~m} 36 \mathrm{f} \\
30 \\
52 \text { years } \\
{[35-73]} \\
\text { foraminal exf } \\
\text { single level } \\
\text { L2-L5 }\end{array}$ & $\begin{array}{l}\text { KARL } \\
\text { STORZ PED }\end{array}$ & $\begin{array}{l}12 \text { months } \\
0 \text { non resp }\end{array}$ & $\begin{array}{l}\text { pain vas } 8.2 \text { to } 1.2 \text { diff } \\
85 \% \text { ODI } 78 \text { to } 8 \text { diff } \\
90 \% \\
\text { Complications } 6.1 \\
\text { Reoperation Rate } 7.6\end{array}$ & $2007^{67}$ \\
\hline Lee & $\begin{array}{l}\text { Radiculopathy, } \\
\text { deficit, sequester }\end{array}$ & $4,5,8$ & $\begin{array}{l}\mathrm{N}=116 \mathrm{~m} 43 \mathrm{f} \\
73 \\
36 \text { years } \\
{[18-65]} \\
\text { single level } \\
\text { L2 S1 }\end{array}$ & $\begin{array}{l}\text { Intra+Yess } \\
\text { PELD }\end{array}$ & $\begin{array}{l}14.5 \text { months } \\
{[9-20]} \\
\text { o non resp }\end{array}$ & $\begin{array}{l}\text { Pain leg } 7.5 \text { to } 2.6 \text { diff } \\
65 \% \text { GPE m } 45 \text { exc } 47 \\
\text { good } \\
6 \text { poor } \\
\text { return } 2 \text { work av } 14 \\
\text { days }[1-48 \text { days }] \\
\text { rec } 0 \\
\text { Complications } 0 \\
\text { Reoperation Rate } 0\end{array}$ & $2007^{68}$ \\
\hline
\end{tabular}

Since we introduced the methodology of spine endoscopy in 2001 we are able to compare results of TFE Vs micro discectomy during that period, using a group practice that offers both techniques. There is a very extensive study of MLD vs Endoscopy also reported by Kotilainen in $1994 .{ }^{69}$ 
In a 2006 study by Lee et al. ${ }^{72}$ post op radiological evaluation based study. Although the clinical outcomes were similarly satisfactory in both groups, PELD is a less invasive procedure for the muscles and soft tissues of the back than open microdiscectomy in selected cases. A 2007 study by Sasani ${ }^{67}$ about far lateral herniations treated by TFE, a report of 66 patients. It was effective in removal of total fragment and achieve a pain free status in majority.

Following 2 studies of 2008 and 2009 by Ruetten ${ }^{73,74}$ are comparative studies of TFE and MLD one for standard virgin untreated herniations and one for recurrences. They have been summarized in Table 4. The clinical results of the full-endoscopic technique were equal to those of the microsurgical technique. TFE had reduced traumatization. Fullendoscopic surgery (including interlaminar FE) is a sufficient and safe supplementation and alternative to microsurgical procedures. ${ }^{46}$ Lee et al. ${ }^{75}$ found bothoth PELD and repeat OLM showed favorable outcomes for recurrent disc herniation, but PELD had advantages in terms of shorter operating time, hospital stay, and disc height preservation. The prevention of recurrence was achieved in interlaminar access by annular sealing mainly in percutaneous interlaminar FE. ${ }^{76}$ Another study in 2009 has demonstrated that FE can be day care surgery and achieved similar results. ${ }^{77}$

In 2010 in a systematic review, ${ }^{78}$ a randomized controlled trial, 7 non-randomized controlled trials, and 31 observational studies were identified. The data from these 31 studies have been sourced and reanalyzed in Table 1, Table 2, Table 3. Studies were heterogeneous regarding patient selection, indications, operation techniques, follow-up period and outcome measures, and the methodological quality of these studies was poor.

\begin{tabular}{|c|c|c|c|c|c|}
\hline $\begin{array}{l}\text { Authors/year/ } \\
\text { hernation type }\end{array}$ & procedure & $\begin{array}{l}\text { operating } \\
\text { time } \\
(\mathrm{min}) \\
\text { /blood } \\
\text { loss } \\
(\mathrm{ml})\end{array}$ & $\begin{array}{l}\text { clinical } \\
\text { outcome } \\
\text { criteria }\end{array}$ & Reoperations & complications \\
\hline $\begin{array}{l}\text { Ruetten et al, } \\
2008 \text { lumbar } \\
\text { recurrent }\end{array}$ & $\begin{array}{l}\text { TFE, IL FE } \\
\text { sequestrectomy }\end{array}$ & $\begin{array}{l}24(14- \\
43) / \\
0\end{array}$ & $\begin{array}{l}\text { VAS back: } 14 \\
\text { to } 15 \\
\text { VAS leg: } 79 \text { to } \\
8 \\
\text { ODI: } 80 \text { to } 20 \\
\text { NASS pain: } \\
4.3 \text { to } 2.1 \\
\text { NASS } \\
\text { neurology: } 2.5 \\
\text { to } 2.1 \\
\text { RTW } 28 \text { days }\end{array}$ & $\begin{array}{l}5 \text { overall } \\
(11.1 \%) \\
3 \text { for } \\
\text { recurrent } \\
\text { herniation } \\
2 \text { for } \\
\text { persistent } \\
\text { leg pain }\end{array}$ & $\begin{array}{l}\text { dural tears: } 1 \\
\text { transient postopdysesthesia: } 2 \\
\text { serious complications: } 6 \%\end{array}$ \\
\hline $\begin{array}{l}* * \text { overall } 9 \text { poor } \\
\text { outcomes no } \\
\text { subgrouping }\end{array}$ & $\begin{array}{l}\text { microsurgical } \\
\text { sequestrectomy } \\
\text { (paramedian } \\
\text { approach) }\end{array}$ & $\begin{array}{l}58 \\
(39-91) / \\
41 \\
(10-205)\end{array}$ & $\begin{array}{l}\text { VAS back: } 15 \\
\text { to } 14 \\
\text { VAS leg: } 85 \text { to } \\
10 \\
\text { ODI: } 84 \text { to } 21 \\
\text { NASS pain: } \\
4.5 \text { to } 2.1 \\
\text { NASS } \\
\text { neurology: } 2.3 \\
\text { to } 2.3 \\
\text { RTW } 52 \text { days }\end{array}$ & & \\
\hline
\end{tabular}




\begin{tabular}{|c|c|c|c|c|c|}
\hline $\begin{array}{l}\text { Ruetten et al, } \\
2008 \text { lumbar } \\
\text { (median, lateral, } \\
\text { extraforaminal) }\end{array}$ & $\begin{array}{l}\text { endoscopic } \\
\text { interlaminar or } \\
\text { transforaminal } \\
\text { sequestrectomy }\end{array}$ & $\begin{array}{l}22 \\
(13-46) / \\
0\end{array}$ & $\begin{array}{l}\text { VAS back: } 19 \\
\text { to } 11 \\
\text { VAS leg: } 75 \text { to } \\
8 \\
\text { ODI: } 75 \text { to } 20 \\
\text { NASS pain: } \\
4.6 \text { to } 2.1 \\
\text { NASS } \\
\text { neurology: } 3.1 \\
\text { to } 2.1 \text { RTW } 25 \\
\text { days }\end{array}$ & $\begin{array}{l}9 \text { overall } \\
(9.9 \%) \\
6 \text { for } \\
\text { recurrent } \\
\text { herniation } \\
2 \text { for } \\
\text { repeated } \\
\text { recurrence } \\
1 \text { fusion for } \\
\text { progressive } \\
\text { LBP }\end{array}$ & $\begin{array}{l}\text { transient postoperative dysesthesia: } 3 \\
\text { serious complications: } 0\end{array}$ \\
\hline $\begin{array}{l}* * 13 \text { over all } \\
\text { poor outcomes } \\
\text { no subgroupings }\end{array}$ & $\begin{array}{l}\text { microsurgical } \\
\text { sequestrectomy } \\
\text { (paramedian or } \\
\text { lateral) }\end{array}$ & $\begin{array}{l}43 \\
(34-72) / \\
45 \\
(5-235)\end{array}$ & $\begin{array}{l}\text { VAS back: } 15 \\
\text { to } 18 \\
\text { VAS leg: } 71 \text { to } \\
9 \\
\text { ODI: } 73 \text { to } 24 \\
\text { NASS pain: } \\
4.2 \text { to } 2.3 \\
\text { NASS } \\
\text { neurology: } 2.9 \\
\text { to } 1.9 \\
\text { RTW } 49 \text { days }\end{array}$ & $\begin{array}{l}10 \text { overall } \\
(11.5 \%) \\
5 \text { for } \\
\text { recurrent } \\
\text { herniation } \\
5 \text { fusions for } \\
\text { progressive } \\
\text { LBP }\end{array}$ & $\begin{array}{l}\text { transient postoperative dysesthesia: } 5 \\
\text { postoperative bleeding: } 2 \text { delayed wound- } \\
\text { healing: } 2 \text { soft tissue infection: } 1 \\
\text { transient urinary retention: } 3 \text { serious } \\
\text { complications: } 0\end{array}$ \\
\hline
\end{tabular}

The eight trials (randomized and non-randomized; Table 5) did not find any statistically significant differences in leg pain reduction between the transforaminal endoscopic surgery group (89\%) and the open microdiscectomy group (87\%); overall improvement ( 84 vs. $78 \%$ ), re-operation rate ( 6.8 vs. $4.7 \%$ ) and complication rate (1.5 vs. $1 \%$ ), respectively. There has been an added detailed review of evolution of disc surgery in 2011 by Postachini. ${ }^{79}$

Table 5. Present day state of endoscopy for transforaminal lumbar access and surgery.

\begin{tabular}{|c|c|c|c|c|c|c|}
\hline Hermantin $^{70}$ & $\begin{array}{l}\text { randomized } \\
\text { controlled } \\
\text { trial }\end{array}$ & $\begin{array}{l}60 \\
\text { pts }\end{array}$ & $\begin{array}{l}\text { Age } \\
40 \\
\text { av }\end{array}$ & $\begin{array}{l}>3 \\
\text { months } \\
\text { pain }\end{array}$ & $\begin{array}{l}\text { LBP radicular pain, iamage conf } \\
\text { L2S1 disc, cons tt ineffective }\end{array}$ & $\begin{array}{l}\text { Backpain, improvement, } \\
\text { return to work RTW, } \\
\text { patient satisfaction, } \\
\text { complications, } \\
\text { reop }\end{array}$ \\
\hline Krappel $^{85}$ & $\begin{array}{l}\text { randomized } \\
\text { controlled } \\
\text { trial }\end{array}$ & $\begin{array}{l}40 \\
\text { pts }\end{array}$ & 40 & $\begin{array}{l}>1 \\
\text { month }\end{array}$ & $\begin{array}{l}\text { Mri conf disc herniation,pain, deficit, } \\
\text { failed cons tt }\end{array}$ & Mcnab, RTW, complications, reop, cost \\
\hline Mayer $^{42}$ & $\begin{array}{l}\text { randomized } \\
\text { controlled } \\
\text { trial }\end{array}$ & 40 & 41 & 6.9 & $\begin{array}{l}\text { Failed cons tt, small non contained } \\
\text { disc }\end{array}$ & $\begin{array}{l}\text { Back leg pain, disability,symptom } \\
\text { score,RTW,op time,reop }\end{array}$ \\
\hline $\mathrm{Kim}^{86}$ & Retro & 902 & 41 & 11 & Pain,failed constt, single level & $\begin{array}{l}\text { Mcnab, op time, blood loss, } \\
\text { complications, reop, radiology }\end{array}$ \\
\hline Lee $^{72}$ & Retro & 60 & 39 & $>3$ & $\begin{array}{l}\text { Ct mr conf disc, leg pain }>\text { back } \\
\text { unilateral,failed cons tt }\end{array}$ & $\begin{array}{l}\text { Macnab, op time, length of } \\
\text { hospitalization, radiological }\end{array}$ \\
\hline $\mathrm{Lee}^{75}$ & Retro & 54 & 45 & & $\begin{array}{l}\text { Previous open surgery,recurrent } \\
\text { radicular pain,MRI conf disc,failed } \\
\text { cons tt }\end{array}$ & $\begin{array}{l}\text { Back leg pain,ODI,op time,length of } \\
\text { hospitalization,complications,reop }\end{array}$ \\
\hline Ruetten $^{74}$ & $\begin{array}{l}\text { randomized } \\
\text { controlled } \\
\text { trial }\end{array}$ & 200 & 43 & 3 & Radicular pain,deficit,failed cons $\mathrm{tt}$ & $\begin{array}{l}\text { Back leg pain,ODI,satisfaction,op time, } \\
\text { blood loss, compli,reop,NASS score }\end{array}$ \\
\hline Ruetten $^{73}$ & $\begin{array}{l}\text { randomized } \\
\text { controlled } \\
\text { trial }\end{array}$ & 100 & 39 & 2 & $\begin{array}{l}\text { Recurred disc,MRI conf,leg pain, } \\
\text { deficit,failed cons tt }\end{array}$ & $\begin{array}{l}\text { Back leg pain, ODI, satisfaction, op } \\
\text { time, blood loss, compli, reop, NASS } \\
\text { score }\end{array}$ \\
\hline
\end{tabular}

Data source: Minimally invasive surgery for lumbar disc herniation: a systematic review and metaanalysis, Kamper et al. Eur Spine J (2014) 23:1021-1043. The data has been used to read and collate the 
references and make meaningful groups based on timeline. These studies are the only studies which have been recently considered to appreciate the state of endoscopy at present.

In 2013 a study comparing learning curve of MLD and FE it was found it is steep but not hard to master. ${ }^{81}$ There is a recent French instructional course on disc surgery $2013^{82}$ by A. Blamoutier that compares microdiscectomy and full endoscopy.

Ruetten et al. reported no difference in terms of lumbar or radicular pain, or Oswestry or North American Spine Society (NASS) pain or neurology scores at 2 years' follow-up. Gotfryd and Avanzi ${ }^{83}$ and Nellensteijn ${ }^{78}$ performed systematic literature reviews. The former compared standard discectomy (SD), micro- or microlumbar discectomy (MD) and endoscopy (MED and FE). Endoscopy and MED were preferable to SD in terms of hospital stay and bleeding but not of clinical result. The latter assessed efficacy in FE and MED, they concluded that there was no difference between the techniques in terms of pain, complications or recurrence.

\section{The Current State of Endoscopic Disc Surgery}

Overall, the endoscopic techniques had shorter operating times, less blood loss, less operative site pain, and faster postoperative rehabilitation/shorter hospital stay/faster return to work than the microsurgical techniques. ${ }^{84}$ There were no significant differences in the main clinical outcome criteria between the endoscopic and the microsurgical techniques in any of the trials. All 5 studies had fewer complications with the endoscopic technique and this was statistically significant in 2 of the studies. One study showed a lower rate of revision surgeries requiring arthrodesis with the endoscopic technique. All 5 studies that could be considered originate from experienced investigators and all 4 randomized controlled trials came from one group (Ruetten et al). This limits the transferability of their results to surgeons less experienced in endoscopic disc surgery.

In this review of $2014^{84}$ which talks about tissue damage in TFE Vs MD, Patients in the PELD group had less blood loss $(\mathrm{p}<0.01)$, shorter hospitalization hours $(\mathrm{p}<0.01)$ and smaller surgical wounds $(\mathrm{p}<0.01)$ than the patients underwent traditional OD surgery. MacNab criteria based evaluation showed levels of satisfaction were above $90 \%$ in both groups postoperative six months. There was no significant difference in pain index between the two groups $(p>0.05)$. Furthermore, the levels of CRP, CPK and IL- 6 in the PELD group were all lower than those in the OD group with a significant difference ( $p<$ 0.01). The PELD had less damage to human tissues than the traditional OD.

Three randomized controlled trials (Hermantin, ${ }^{70}$ Krappel, ${ }^{85}$ and Mayer ${ }^{42}$ ) and three retrospective studies (Kim, ${ }^{86}$ Lee, $^{72}$ and Lee ${ }^{75}$ ) compare TFE and MD (Table 5). Taken together, this is Level 4 and 5 evidence that transforaminal endoscopy is not superior to microdiscectomy for back pain $(n=154)$, leg pain, ${ }^{42,75}$ (one randomized trial, one nonrandomized; $\mathrm{n}=100$ ) or patient satisfaction (one randomized trial; $\mathrm{n}=60$ ) and very low quality evidence that there is no difference in function or general improvement (three randomized trials, three nonrandomised trials $\left.\mathrm{s}^{42,70,72,85} ; \mathrm{n}=1,169\right)$ at any time point. 
There is Level 4-5 evidence from two randomized controlled trials $(n=80)$ that there is no difference in the proportion of people who return to work ${ }^{42,85}$ one further randomized controlled trial [70] $(n=60)$ measured return to work in days but does not report sufficient detail to estimate the between-group difference.

There is Level 5 evidence from two randomized controlled trials and three nonrandomised studies $(n=1,109)$ that operative time ${ }^{42,72,75,85,86}$ is not different; mean operative time was $55.2 \mathrm{~min}$ for TFE and $60.3 \mathrm{~min}$ for MD.

Level 5 evidence suggests that there is no difference in length of hospital stay ${ }^{72,75,85}$ ( $\mathrm{n}=$ 154) or rate of complications $\mathrm{s}^{70,75,85,86}(\mathrm{n}=1,056)$.

There is Level 5 evidence from three randomized controlled trials ${ }^{42,70,85}$ (total $\mathrm{n}=160$ ) of no difference in reoperation rate, but low quality evidence that TFE results in more reoperations when two non-randomised, retrospective studies ${ }^{75,86}$ (total $n=1,129$ ) are included (OR; 1.69, CI 1.06-2.71). One randomized controlled trial ${ }^{85}(\mathrm{n}=40)$ reported that TFE may be more expensive than MD.

\section{Mixed randomized controlled trials}

Two randomized controlled trials by Ruetten ${ }^{73,74}$ ( $n=200$ and $n=100$ respectively) allocated patients either to interlaminar or transforaminal approach, or to microdiscectomy. The interlaminar approach was generally used for herniations inside the spinal canal and TF for intra- and extra-foraminal herniations, although the final decision was at the discretion of the surgeon.

One study included patients with first time disc herniations, ${ }^{74}$ the other only patients with recurrent disc herniations who previously had discectomy surgery ${ }^{73}$ at the same level. These studies were both judged to have a high risk of bias. As such all pooled analyses provide low quality evidence. There is Level 4 evidence that the effects of minimally invasive surgery (IL or TF) for patients with first time ${ }^{74}$ and recurrent disc herniations ${ }^{73}$ are not different to MD on back pain, leg pain or function at any time point.

The results being same or similar, it would be important to know how these results are achieved. It is not possible to ignore the morbidity with open surgery and limitation which medical comorbidities will have on choice of surgery. In patients with severe medical comorbidities only way we can offer pain relief is surgery under awake and aware status under local anesthesia.

\section{Conclusion and recommendations}

Conclusions regarding the differences in effect between transforaminal discectomy and conventional micro discectomy are difficult to draw due to the lack of high quality studies. While available evidence also suggests that outcomes are comparable, welldesigned research of sufficient power could change estimates of effect.

A randomized controlled trial, with robust methodology and adequate sample size, comparing transforaminal surgery to conventional micro discectomy, is needed. The present analysis covers both randomized and non-randomized studies with due consideration to bias in non-randomized studies. Lack of power is a problem common to 
most of the included randomized controlled trials. It is likely that the lack of difference observed between TFE and MD in studies conducted to date is a Type II error due to insufficient power.

A study should consider changed philosophy, clinical concerns, indications for surgery, advantages of transforaminal approach, location of disc fragment, complications, muscle damage, operative time, standardized patient-relevant outcomes, and sample size, allocation, and blinding where possible. A cost-effectiveness study should also be conducted.

Whenever a discussion is centered on full endoscopy and micro discectomy it always bypasses several issues. More precise diagnosis of pain generators, better correlation of image and symptoms, precise targeting of the pathology, possibility of doing surgery under local anesthesia and having patient awake and aware, surgery being stitchless, possibility of doing surgery to mitigate medical comorbidities, are inherent in transforaminal endoscopy. Even after ignoring these important advantages the discussion then only centers on decompression of nerve roots and approach related morbidity. The way surgery is executed and why is not given its due.

When we are discussing the issue surgeons who are at cutting edge of this technology, we should discuss state of the art, as with arrow of time it will then slowly percolate to all interested surgeons. Repeatability of outcomes based on expertise in execution alone may be politically sensitive issue. Objections are raised about transforaminal access by nonendoscopic surgeons based on what works best in an individual surgeon's hands. Here, the surgeon factor must be considered. Each surgeon will have different levels of skills for the procedures that they perform. It is important that this factor be considered when advising patients of the best technique to undergo. It will be a joint decision by the patient and surgeon, depending on the surgical the needs of the patient and surgeons' expertise.. Recently a transiliac access is described for L5-S1 transforaminal surgery. It is thus possible to do a transforaminal surgery at L5-S1. ${ }^{87,88}$

\section{Discussion}

It is unusual to have a review paper by two actively practicing surgeon authors who are living through the development of an approach to the lumbar spine that encompasses accurately, the historical and technical development of this least invasive access. This discussion provides answers to common questions and the current realization that the costly fusion implants can be bypassed for most degenerative painful conditions. This paper summarizes how we can surgically address the painful conditions by visualizing and then decompressing, ablating, and irrigating the source of pain. These are techniques that can only be consolidated by surgeons who not only have experience and training in current traditional techniques, but choose to dedicate their careers to new approach of potential and cost-effectiveness from not "burning bridges" to other more costly procedures, which may be partly driven by economic considerations and reimbursement.

A number of questions about this technique are answered below. 
The reason why more surgeons are not embracing this technique is because it was developed by surgeons in private practice and is not available in teaching institutions and training programs. The fellowship programs are also threatening their graduates by withholding board certifications of any graduate who does not adhere to traditional concepts taught at their institution of learning. The teachers are also critical of what they do not do and they do not take the time to learn. Those who decide on their own, and take the time to practice, will take approximately 70 cases to reach a $90 \%$ good/excellent success rate ${ }^{89}$ by Macnab criteria. They also have to essentially have a near-zero complication success rate or experts sought by plaintiff lawyers will get them to give their personal opinion as factual, insulating themselves for to civil liability of their testimony.

In this situation, the best way to learn is working under and with a master in transforaminal surgery and understand not only its method but philosophy. Training on sawbones models are available, but does not substitute for mentorship. This is not a "see one, do one, teach one" procedure. There are clear crystallized learning objectives:

1. Proper Clinical diagnosis of likely pain generators

2. Identification of pain generators in images and correlation with clinical presentation

3. Targeting pain generators precisely through the foramen, and once the scope is introduced identifying structures correctly

4. Extending reach to pathology using newer instruments like a hook.

5. Confirming adequacy of surgery.

6. Avoiding complications.

While the transforaminal portal is the least invasive, endoscopic posterior approaches with a movable cannula is less invasive than a dorsal approach using mini retractors and a microscope. In the end it is the surgeon factor that controls the eventual outcome of surgery.

A pressing question about this technique is the incidence and cause of dysesthesia, a condition that is common and not preventable due to the need to decompress the dorsal root ganglion (DRG) as a major anatomic cause of pain which most times is out of proportion to what the imaging studies show. In fact, the DRG can cause dysesthesia merely from the increased blood flow after decompression, but also from the likely hood that it can be irritated by bleeding form the surgical site and ablation and manipulation of surgical instruments near the DRG even if it is only retracted gently. The risk of dysesthesia has been studied by Yeung and reported in presentation and posters at international spine meetings. There is also published literature suggesting surgical irritation as the cause and using a floating cannula as a way to prevent excessive DRG handling. ${ }^{90}$

The dysesthesia cannot be completely eliminated, but if a furcal nerve is identified with the endoscope and the nerve is manipulated or ablated, the incidence increases to $50 \%$, but over $95 \%$ resolve completely with gabapentin, transforaminal epidural blocks and sympathetic blocks. The surgeon, therefore should be adept at performing these blocks. The literature has indicated the dysesthesia rate as high as $26 \% .{ }^{91}$ 
Our paper emphasizes the use of local anesthesia because this is by far the safest form of anesthesia. The author [ATY] has had his own procedure performed on himself and the experience allowed him to inform the operating surgeon when there is pain associated with the transforaminal decompressive procedure. The location of the pain and its distribution is also not always in the expected dermatome or even on the ipsilateral side of the patho-anatomy. The inflammatory membrane can cause pain in an adjacent dermatome or even a distant dermatome like groin pain produced while working at L 4-5 or L 5-S1 and during endoscopic probing. A prospective study reported at international spine meetings found no need for neuro monitoring when local anesthesia is utilized. ${ }^{92}$

Reoperation rates are dependent on surgeon expertise and experience. There may be a trade-off in the early experience of the surgeon's learning curve. We all go through a learning curve. Even after over 10,000 procedures, the technique is still evolving as newer equipment and imaging capabilities in the operating room are expected to improve results. The recurrence and re-operation rates in the literature do not reflect the true recurrence or re-operation rates. In the author's hands, recurrence is approximately $6 \%$, incomplete decompression $6 \%$, and complications $1 \%$. We do acknowledge that instability and a very tight central canal still need complementary solutions and may be areas for future research and development in this field.

Cost studies are available, but since highlighting higher costs for endoscopy have factored in cost of instruments in every case, this is not reality. In one published study of 2013 February the study is inconclusive about costs and the economic model. ${ }^{93}$

The surgeon factor is still too elusive for meaningful data to emerge. The senior author (ATY) has instigated a highly selected payment structure based on a "guaranteed outcome spectrum of projected improvement" with a complication safety factor of $99 \%$ ( $1 \%$ complication rate) or the patient can request his money back. This is for a full list price payment. The prediction is based on the patient obtaining a certain level of improvement from diagnostic and therapeutic injections performed personally by the surgeon. By doing this, the surgeon can weigh in the psychosocial factors that are known to affect surgical outcomes. Certainly, just eliminating implant and hardware costs will also provide significant savings.

Recently the quality of the equipment available has improved, particularly in respect to the instrumentation systems and HD cameras and monitors. The development of articulated and bendable instruments, endoscopic osteotomes and reamers has all made surgical access better. This has improved the ability to teach and demonstrate technique and its philosophy and reduced the exposure of multiple patients to surgeons learning these skills. It has thus shortened the learning curve and almost flattened it. Access through the transforaminal approach also allows widening of the foramen to ensure that the exiting and traversing nerve roots are free. This is emerging as a new validated standard. ${ }^{94}$

\section{References}

1. Yeung AT, Gore SR. Evolving methodology in treating discogenic back pain by Selective Endoscopic Discectomy (SED) and thermal annuloplasty. Journal of Minimally Invasive Spinal Technique 2001;1:8-16. 
2. Gore SR, Yeung AT. Identifying sources of discogenic pain. Jour Minimally Invasive Spinal Technique 2003;3(1):21-4.

3. Yeung AT, P.M. Tsou Posterolateral endoscopic excision for lumbar disc herniation: surgical technique, outcome, and complications in 307 consecutive cases Spine (Phila Pa 1976), 27 (7) (2002), pp. 722-731

4. Yeung AT: Minimally invasive surgery with the Yeung endoscopic spine system (YESS). Surg Tech Int 2000;VIII:267-27730.

5. Yeung AT, Yeung CA: Advances in Endoscopic Disc and Spine Surgery: The Foraminal Approach. Surgical Tech Int XI, 2003 June; 253-61

6. Yeung AT: Percutaneous Endoscopic Discectomy: the Posterolateral Approach, Minimal Access Spine Surgery, 2nd Edition, edited by Drs Regan and Lieberman, Quality Medical Publishing October, 2003.

7. Yeung AT, Gore SR In-vivo Endoscopic Visualization of Patho-anatomy in Symptomatic Degenerative Conditions of the Lumbar Spine II: Intradiscal, Foraminal, and Central Canal Decompression. Surg Technol Int. 2011 Dec 1;XXI:299-319

8. Yeung AT, Yeung CA In-vivo endoscopic visualization of patho-anatomy in painful degenerative conditions of the lumbar spine. Surg Technol Int. 2006;15:243-56.

9. Yeung AT, MD The Evolution and Advancement of Endoscopic Foraminal Surgery: One Surgeon's Experience Incorporating Adjunctive Technologies SAS Journal Volume 1, Issue 3 , Pages 108-117, September 2007

10. Parviz Kambin, MD Arthroscopic and Endoscopic Spinal Surgery: Text and Atlas: Second Edition Edited by: P. Kambin (C) Humana Press Inc., Totowa, NJ History of Surgical Management of Herniated Lumbar Discs From Cauterization to Arthroscopic and Endoscopic Spinal Surgery

11. A.R.Ponyton, D A Ofarrell, D.Mulcahy,N T corriganand F Mcmanus Chymopapain chemonucleolysis: a review of 105 cases J.R. Coll. Surg. Edinb., 43, December 1998, 407-409

12. Smith L. Enzyme dissolution of the nucleus pulposus in humans. JAMA 1964; 187:137-140.

13. Noordby E, Fraser R, Javid M spine update chemonucleolysis: spine 1996 ;21:1102-1105

14. Hijikata S. Percutaneous nuclectomy: A method of percutaneous nuclear extraction. J Toden Hospital 1975; 5:39-44.

15. Onik G, Helms C, Ginsburg L, Hoaglund FT, Morris J. Percutaneous lumbar discectomy using a new aspiration probe. AJNR 1985; 6:290-293.

16. Onik G, Helms CA, Ginsberg L, Hoaglund FT, Morris J. Percutaneous lumbar discectomy using a new aspiration probe: Porcine and cadaver model. Radiology 1985; 155:251-252.

17. P. Kambin, S. Sampson Posterolateral percutaneous suction-excision of herniated lumbar intervertebral discs. Report of interim results Clin Orthop Relat Res (207) (1986), pp. 37-43

18. Mathews HH Transforaminal endoscopic microdiscectomy. Neurosurg Clin N Am 1996 Jan;7 (1): 59-63.

19. K. Foley, M. Smith Microendoscopic discectomy Oper Tech Neurosurg, 3 (1997), pp. 301-307

20. J. Destandau A special device for endoscopic surgery of lumbar disc herniationNeurol Res (21) (1999), pp. 39-42 
21. Kuslich SD, Ulstrom CL, Michael CJ. The tissue origin of low back pain and sciatica: a report of pain response to tissue stimulation during operations on the lumbar spine using local anesthesia. Orthop Clin North Am. 1991 Apr;22(2):181-7.

22. Mirkovic, S.R., D.G. Schwartz, and K.D. Glazier, Anatomic considerations in lumbar posterolateral percutaneous procedures. Spine, 1995. 20(18): p. 1965-71.

23. Knight M, Goswami A, Patko JT (1999) Endoscopic laser foraminoplasty and a aware-state surgery: a treatment concept and 2-year outcome analyses. Arthroskopie 12:62-73

24. Knight MT, Ellison DR, Goswami A et al (2001) Review of safety in endoscopic laser foraminoplasty for the management of back pain. J Clin Laser Med Surg 19:147-157 29.

25. Knight MT, Vajda A, Jakab GV et al (1998) Endoscopic laser foraminoplasty on the lumbar spine - early experience. Minim Invasive Neurosurg 41:5-9

26. Knight MT, Goswami A, Patko JT et al (2001) Endoscopic foraminoplasty: a prospective study on 250 consecutive patients with independent evaluation. J Clin Laser Med Surg 19:73-81E

27. Hoogland T (2003) Transforaminal endoscopic discectomy with forminoplasty for lumbar disc herniation. Surg Tech Orthop 1-6

28. Hoogland T, Scheckenbach C (1998) Die endoskopische transforminale diskektomie bei lumbalen bandscheibenforfallen. Orthop Prax 34:352-355

29. Hoogland T, Schubert M, Miklitz B et al (2006) Transforaminal posterolateral endoscopic discectomy with or without the combination of a low-dose chymopapain: a prospective randomized study in 280 consecutive cases. Spine 31:E890-E897

30. Hoogland T, van den Brekel-Dijkstra K, Schubert M et al (2008) Endoscopic transforaminal discectomy for recurrent lumbar disc herniation: a prospective, cohort evaluation of 262 consecutive cases. Spine 33:973-978

31. W Rauschning. Anatomical basics in regard of minimal invasive lumber spine procedures. The Internet Journal of Minimally Invasive Spinal Technology. 2008 Volume 3 Number 4

32. Riew, et.al.: The effect of nerve-root injections (SNRB) on the need for operative treatment of lumbar radicular pain. J Bone Joint Surg Vol. 82-A, No. 11, November 2000 p1589-1593

33. Wang H, Huang B, Li C, Zhang Z, Wang J, Zheng W, Zhou Y Learning curve for percutaneous endoscopic lumbar discectomy depending on the surgeon's training level of minimally invasive spine surgery. Clin Neurol Neurosurg. 2013 Oct;115(10):1987-91. doi: 10.1016/ j.clineuro.2013.06.008. Epub 2013 Jul 2

34. Osman SG, Nibu K, Panjabi MM, Marsolais EB, Chaudhary R, Transforaminal and posterior decompressions of the lumbar spine. A comparative study of stability and intervertebral foramen area. Spine, 1997. 22(15): p. 1690-5

35. Ozer AF1, Oktenoglu T, Sasani M, Bozkus H, Canbulat N, Karaarslan E, Sungurlu SF, Sarioglu AC. Preserving the ligamentum flavum in lumbar discectomy: a new technique that prevents scar tissue formation in the first 6 months postsurgery. Neurosurgery. 2006 Jul;59(1 Suppl 1):ONS126-33; discussion ONS126-33.

36. Schreiber A, Suezawa Y (1986) Transdiscoscopic percutaneous nucleotomy in disk herniation. Orthop Rev 15:35-38

37. Suezawa Y, Schreiber A (1988) Percutaneous nucleotomy with discoscopy. 7 years experience and results. Z Orthop Ihre Grenzgeb 126:1-7 6. 
38. Leu H, Schreiber A (1991) Percutaneous nucleotomy with disk endoscopy-a minimally invasive therapy in non-sequestrated intervertebral disk hernia. Schweiz Rundsch Med Prax 80:364-368

39. Schreiber A, Leu H (1991) Percutaneous nucleotomy: technique with discoscopy. Orthopedics 14:439-444 49.

40. Savitz MH (1994) Same-day microsurgical arthroscopic lateral approach laserassisted (SMALL) fluoroscopic discectomy. J Neurosurg 80:1039-1045

41. Savitz MH, Doughty H, Burns P (1998) Percutaneous lumbar discectomy with a working endoscope and laser assistance. Neurosurg Focus 4:E9

42. Mayer HM, Brock M: Percutaneous Endoscopic Discectomy: Surgical Technique and Preliminary Results Compared to Microsurgical Discectomy. J Neurosurg 1993: 78 : 216-225

43. Ditsworth DA (1998) Endoscopic transforaminal lumbar discectomy and reconfiguration: a posterolateral approach into the spinal canal. Surg Neurol 49:588-597 1993

44. Haag M (1999) Transforaminal endoscopic microdiscectomy. Indications and shortterm to intermediate-term results. Orthopade 28:615-621

45. Hochschuler SH (1991) Posterior lateral arthroscopic microdiskectomy. Semin Orthop 6:113-114

46. Kambin P (1992) Arthroscopic microdiscectomy. Arthroscopy 8:287-295

47. Yeung AT, Tsou PM (2002) Posterolateral endoscopic excision for lumbar disc herniation: surgical technique, outcome, and complications in 307 consecutive cases. Spine 27:722-731

48. Wojcik AS (2004) Endoscopically assisted percutaneous lumbar discectomy. Ortop Traumatol Rehabil 6:259-263

49. Lew SM, Mehalic TF, Fagone KL (2001) Transforaminal percutaneous endoscopic discectomy in the treatment of far-lateral and foraminal lumbar disc herniations. $\mathbf{J}$ Neurosurg 94:216-220

50. Hoogland T (2003) Transforaminal endoscopic discectomy with forminoplasty for lumbar disc herniation. Surg Tech Orthop 1-6

51. Eustacchio S, Flaschka G, Trummer M et al (2002) Endoscopic percutaneous transforaminal treatment for herniated lumbar discs. Acta Neurochir (Wien) 144:997-1004

52. Chiu JC (2004) Evolving transforaminal endoscopic microdecompression for herniated lumbar discs and spinal stenosis. Surg Technol Int 13:276-286

53. Ahn Y, Lee SH, Park WM et al (2004) Percutaneous endoscopic lumbar discectomy for recurrent disc herniation: surgical technique, outcome, and prognostic factors of 43 consecutive cases. Spine 29:E326-E332

54. Suess O, Brock M, Kombos T (2005) Motor nerve root monitoring during percutaneous transforaminal endoscopic sequestrectomy under general anaesthesia for intra- and extraforaminal lumbar disc herniation. Zentralbl Neurochir 66:190-201

55. Schubert M, Hoogland T (2005) Endoscopic transforaminal nucleotomy with foraminoplasty for lumbar disk herniation. Oper Orthop Traumatol 17:641-661

56. Ruetten S, Komp M, Godolias G (2005) An extreme lateral access for the surgery of lumbar disc herniations inside the spinal canal using the full-endoscopic uniportal transforaminal approach-technique and prospective results of 463 patients. Spine $30: 2570-2578$ 
57. Ramsbacher J, Kern BC, Kombos T et al (2000) Transforaminal endoscopic sequestrectomy: indications, operative technique, and first clinical experience. Neurosurg Q 10:224-227

58. Scheckenbach C, Hoogland T (1999) Endoskopische transforminale diskektomie (ETD) - Ergebnisse nach 2 jahren (Endoscopic transforaminal discectomy). Orthopadische Praxis 35:104-105

59. Morgenstern R, Morgenstern C, Abelleo A et al (2005) Eine studie von 144 fallen nach unterzogener endoskopischer lendenwirbelsaulenchirurgie-klassische rehabilitation im vergleich zur FPZ methode (A study on 144 cases after lumbar spine endoscopic surgery. Classical rehabilitation vs. FPZ machines system). Orthopadische Praxis 41:674-681

60. Tzaan WC (2007) Transforaminal percutaneous endoscopic lumbar discectomy. Chang Gung Med J 30:226-234

61. Shim YB, Lee NY, Huh SH et al (2007) Endoscopic spinal surgery for herniated lumbar discs. J Korean Neurosurg Soc 41:241-245

62. Jang JS, An SH, Lee SH (2006) Transforaminal percutaneous endoscopic discectomy in the treatment of foraminal and extraforaminal lumbar disc herniations. J Spinal Disord Tech 19:338- 343

63. Iprenburg M (2007) Transforaminal endoscopic surgery - technique and provisional results in primary disc herniation. Eur Musculoskelet Rev 73-76

64. Choi G, Lee SH, Bhanot A et al (2007) Percutaneous endoscopic discectomy for extraforaminal lumbar disc herniations: extraforaminal targeted fragmentectomy technique using working channel endoscope. Spine 32:E93-E99

65. Kafadar A, Kahraman S, Akboru M (2006) Percutaneous endoscopic transforaminal lumbar discectomy: a critical appraisal. Minim Invasive Neurosurg 49:74-79

66. Hoogland T, van den Brekel-Dijkstra K, Schubert M et al (2008) Endoscopic transforaminal discectomy for recurrent lumbar disc herniation: a prospective, cohort evaluation of 262 consecutive cases. Spine 33:973-978

67. Sasani M, Ozer AF, Oktenoglu T et al (2007) Percutaneous endoscopic discectomy for far lateral lumbar disc herniations: prospective study and outcome of 66 patients. Minim Invasive Neurosurg 50:91-97

68. Lee S, Kim SK, Lee SH et al (2007) Percutaneous endoscopic lumbar discectomy for migrated disc herniation: classification of disc migration and surgical approaches. Eur Spine J 16:431-437.

69. Kotilainen E Microinvasive lumbar disc surgery. A study on patients treated with microdiscectomy or percutaneous nucleotomy for disc herniation. Ann Chir Gynaecol Suppl. 1994;209:1-50.

70. Hermantin FU, Peters T, Quartararo L, et al: A prospective randomized study comparing the results of open discectomy with those of video-assisted arthroscopic microdiscectomy. J Bone Joint Surg 81-A (7): 958-965, 1999

71. Tsou PM, Yeung AT: Transforaminal endoscopic decompression for radiculopathy secondary to intra-canal non-contained lumbar disc herniations: outcome and technique. Spine Journal 2002. 2:41-48.

72. Lee SH, Chung SE, Ahn Y, Kim TH, Park JY, Shin SW Comparative radiologic evaluation of percutaneous endoscopic lumbar discectomy and open microdiscectomy: a matched cohort analysis. Mt Sinai J Med. 2006 Sep;73(5):795-801. 
73. Ruetten S1, Komp M, Merk H, Godolias G Recurrent lumbar disc herniation after conventional discectomy: a prospective, randomized study comparing fullendoscopic interlaminar and transforaminal versus microsurgical revision. J Spinal Disord Tech. 2009 Apr;22(2):122-9. doi: 10.1097/BSD.0b013e318175ddb4

74. Ruetten S1, Komp M, Merk H, Godolias G. Full-endoscopic interlaminar and transforaminal lumbar discectomy versus conventional microsurgical technique: a prospective, randomized, controlled study. Spine (Phila Pa 1976). 2008 Apr 20;33(9):931-9. doi: 10.1097/ BRS.0b013e31816c8af7.

75. Lee DY, Shim CS, Ahn Y, Choi YG, Kim HJ, Lee SH. Comparison of percutaneous endoscopic lumbar discectomy and open lumbar microdiscectomy for recurrent disc herniation. J Korean Neurosurg Soc. 2009 Dec;46(6):515-21. doi: 10.3340/ jkns.2009.46.6.515. Epub 2009 Dec 31.

76. Kim HS1, Park JY. Comparative assessment of different percutaneous endoscopic interlaminar lumbar discectomy (PEID) techniques. Pain Physician. 2013 JulAug;16(4):359-67.

77. Peng CW1, Yeo W, Tan SB Percutaneous endoscopic lumbar discectomy: clinical and quality of life outcomes with a minimum 2 year follow-up. . J Orthop Surg Res. 2009 Jun 25;4:20. doi: 10.1186/1749-799X-4-20.

78. Jorm Nellensteijn ,Raymond Ostelo, Ronald Bartels, Wilco Peul, Barend van Royen, Maurits van Tulder Transforaminal endoscopic surgery for symptomatic lumbar disc herniations: a systematic review of the literature Eur Spine J (2010) 19:181-204 DOI 10.1007/s00586-009-1155-x

79. Postacchini F, Postacchini R. Operative management of lumbar disc herniation : the evolution of knowledge and surgical techniques in the last century. Acta Neurochir Suppl. 2011;108:17-21. doi: 10.1007/978-3-211-99370-5_4.

80. AT Yeung, M.D. Christopher Yeung, M.D Justin Field, M.D. A COMPARATIVE OUTCOME EVALUATION OF LUMBAR TRANSFORAMINAL ENDOSCOPIC DISCECTOMY VERSUS MICRO-LUMBAR DISCECTOMY FOR LUMBAR DISC HERNIATION 2013 poster presented at ISASS Annual Meeting Vancouver.

81. Hsu HT, Chang SJ, Yang SS, Chai CL. Learning curve of full-endoscopic lumbar discectomy. Eur Spine J. 2013 Apr;22(4):727-33. doi: 10.1007/s00586-012-2540-4. Epub 2012 Oct 17.

82. A. Blamoutier Instructional Course Lectures - French Society of Orthopaedic Society and Traumatology (SoFCOT) 2012 Orthopaedics \& Traumatology: Surgery \& Research Volume 99, Issue 1, Supplement, February 2013, Pages S187-S196

83. Gotfryd, O. Avanzi A systematic review of randomised clinical trials using posterior discectomy to treat lumbar disc herniations Int Orthop, 33 (1) (2009), pp. 11-17

84. Christof Birkenmaier, MD , Martin Komp, MD , Hansjörg F. Leu, MD, Bernd egener, MD , and Sebastian Ruetten, MD, Review of Controlled Studies Comparing Full Endoscopic Procedures for Disc Herniations to Standard Procedures : Pain Physician 2013; 16:335-344 • ISSN 1533-3159

85. Krappel FA, Schmitz R, Bauer E, Harland U (2001) Open or endoscopic nucleotomy? Results of a prospective, controlled clinial trial with independent follow-up, MRI and special reference to cost-effectiveness. Orthopadische Prax 37(3):164-169

86. Kim MJ, Lee SH, Jung ES, Son BG, Choi ES, Shin JH, Sung JK, Chi YC (2007) Targeted percutaneous transforaminal endoscopic diskectomy in 295 patients: comparison with results of microscopic diskectomy. Surg Neurol 68(6):623-631 
87. Osman SG, Marsolais EB. Endoscopic transiliac approach to L5-S1 disc and foramen. A cadaver study. Spine (Phila Pa 1976). 1997 Jun 1;22(11):1259-63.

88. Choi G, Kim JS, Lokhande P, Lee SH. Percutaneous endoscopic lumbar discectomy by transiliac approach: a case report Spine (Phila Pa 1976). 2009 May 20;34(12):E443-6. doi: 10.1097/BRS.0b013e31817c4f39.

89. Rudolf Morgenstern, MD, PhD,Christian Morgenstern, Dipl-Ing, Anthony T. Yeung, MD The Learning Curve in Foraminal Endoscopic Discectomy: Experience Needed to Achieve a 90\% Success Rate SAS Journal . Volume 1, Issue 3 , Pages 100-107, September 2007

90. Cho JY, Lee SH, Lee HY. Prevention of development of postoperative dysesthesia in transforaminal percutaneous endoscopic lumbar discectomy for intracanalicular lumbar disc herniation: floating retraction technique. Minim Invasive Neurosurg. 2011 Oct;54(5-6):214-8. doi: 10.1055/s-0031-1287774. Epub 2012 Jan 27.

91. Dong Yeob Lee, M.D. and Sang-Ho Lee, M.D., Ph.D Microdecompression for Extraforaminal L5-S1 Disc Herniation; The Significance of Concomitant Foraminal Disc Herniation for Postoperative Leg Pain .J Korean Neurosurg Soc. Jul 2008; 44(1): 19-25.Published online Jul 20, 2008. doi: 10.3340/jkns.2008.44.1.19 PMCID: PMC2588286

92. A.T. Yeung \#453 Intra-operative Neuromonitoring in Percutaneous Transforaminal Surgery MIS Techniques and Results http://www.isass.org/abstracts/ isass 12_regular_posters/isass12-453-Intra-operative-Neuromonitoring-inPercutaneous-Transforaminal-Surgery.html

93. R Lewis, N Williams, HE Matar, N Din, D Fitzsimmons, C Phillips, M Jones, A Sutton, K Burton, S Nafees, M Hendry, I Rickard, R Chakraverty and C Wilkinson The clinical effectiveness and costeffectiveness of management strategies for sciatica: systematic review and economic model Health Technology Assessment 2011; Vol. 15: No. 39

94. J.N. Alastair Gibsona, Jonathan G. Cowiea, Menno Iprenburgb. Transforaminal endoscopic spinal surgery: The future 'gold standard' for discectomy? - A review The Surgeon Volume 10, Issue 5, October 2012, 290-296.

\section{Disclosures}

Dr. Gore is a consultant to Karl Storz Germany. Dr. Yeung receives royalties on Wolf products (Rhizotomy Instrument Set, Endoscope System).

\section{Corresponding Author}

Dr. Anthony Yeung, 1635 E Myrtle Ave, Suite 400, Phoenix, AZ 85020; email: ayeung@sciatica.com.

Copyright (C) 2015 ISASS - International Society for the Advancement of Spine Surgery. To see more or order reprints or permissions, see http://ijssurgery.com. 